\title{
Ysla de Panciteria: a preliminary study on the culinary heritage significance of pancit using the heritage documentation approach - the case of Luzon Island, Philippines
}

\author{
Jame Monren T. Mercado ${ }^{1,2,3^{*}}$ (D) and Avi Ben P. Andalecio ${ }^{1,2,4}$
}

\begin{abstract}
Pancit in the Philippines is known as one of the acculturated dishes of the Filipinos from the Chinese. Filipinos accepted the culinary tradition and became as one of the indigenized culinary identities. This qualitative study explicates the culinary heritage significances of pancit in Luzon Island, Philippines using the Heritage Documentation Approach. From that context, this paper highlights the different kinds and variations of pancit based on cultural and heritage aspects of the community and its related characteristics such as the raw ingredients, selling points, cooking equipment, and tools; process of cooking, consumption, and the disposal and recycling of wastes. The researchers make use of different theoretical frameworks from international and national cultural charters and conventions. In the conduct of the research, the researchers used observation as the documentation process, which was based from the cultural heritage mapping. In-depth interviews were utilized to determine the perspectives of the major stakeholders specifically the local government units (LGUs) specifically the Tourism; and Culture and Arts Office; local culinary historians, owners of the restaurants or people who are known for practicing the culinary tradition; and the non-government organizations (NGOs) who are managing and safeguarding the culinary tradition. All of the gathered data were analyzed through the use of thematic analysis and repertory grid. Documentary evidences were assessed and analyzed to determine the perspectives of the previous and current researchers and authors. From the research, a total of 101 kinds of pancit dishes were documented from 8 regions in Luzon. These were all differ from its characteristics and significances, but each dish contributes to the context of the community's story and cultural value. In the end of the research, the researchers identified that the culinary tradition of pancit in Luzon was developed based from regionalism, indigenization, and significance.
\end{abstract}

Keywords: Culinary, Food anthropology, Intangible cultural heritage, Heritage documentation, Luzon Island, Pancit

\footnotetext{
* Correspondence: jtmercado@ust.edu.ph

'College of Tourism and Hospitality Management, University of Santo Tomas,

España Boulevard, 1008 Manila, Philippines

${ }^{2}$ Research Center for Social Sciences and Education, University of Santo

Tomas, España Boulevard, 1008 Manila, Philippines

Full list of author information is available at the end of the article
}

(C) The Author(s). 2020 Open Access This article is licensed under a Creative Commons Attribution 4.0 International License, which permits use, sharing, adaptation, distribution and reproduction in any medium or format, as long as you give

appropriate credit to the original author(s) and the source, provide a link to the Creative Commons licence, and indicate if changes were made. The images or other third party material in this article are included in the article's Creative Commons licence, unless indicated otherwise in a credit line to the material. If material is not included in the article's Creative Commons licence and your intended use is not permitted by statutory regulation or exceeds the permitted use, you will need to obtain permission directly from the copyright holder. To view a copy of this licence, visit http://creativecommons.org/licenses/by/4.0/. 


\section{Introduction}

In the Philippine context, as quoted: "the land in which it was born shaped Philippine food, and so were its cooking processes, ingredients, meal patterns, flavor principles, ways of serving, and social functions" [1]. Food is affected by the historical and cultural development of the society and then passed down through generations. In that sense, it contributes to the uniqueness and differences of food as it is compared from one place to another. Food is considered to be a heritage of the community. The United Nations Educational, Scientific and Cultural Organization (UNESCO) defines heritage as "legacies from the past, what we live with today, and what we individually or collectively pass on to future generations" [2]. Culinary traditions come from the influences and changes of history of a certain place; then society continues to use it from an individual, to the family then to the community; and conserves, preserves and shares it to future generation. Hence, according to [3], culinary tradition is considered to be part of the main domains of the intangible cultural heritage under social practices, rituals, and festive events.

As an identity of the people, food shows significance that contributes to its uniqueness and difference. This significance is based on historical, aesthetic, social, and symbolical aspects. It is important to analyze these details as they contribute to the story and importance of the community and how food evolves and develops as part of the heritage of the people.

Nowadays, culinary heritage is being developed for commercialization [4]. Local foods are commercialized by selling them to the public (locals and non-locals). The local community is motivated because of the local cuisine's potential for a particular market or activity and hope that it can enhance their lifestyle especially in the economic aspect. In short, the local community will be using their own culinary heritage for potential business ventures to generate profit. In putting up a business, an owner must consider the four P's of marketing or also known as the marketing mix: price, place, promotion, and product [5]. As a rule, an owner or an organization must develop the four P's of marketing based on the preference and perspective of the potential market [5]. This can be attained by developing a feasibility study or just by conducting surveys and interviews. In this case of culinary commercialization, theoretically speaking, there will be an alteration or modification in the preparation, cooking process, or presentation of food that will be based on the preference of the target market [5]. Because of this, the significance of the Culinary Heritage maybe deteriorated, but it is reinterpreted and different from the context of the heritage significance.

Different stakeholders in a place prioritize conservation of culinary heritage. There are aspects that affect the significance of the culinary heritage as time, modernization and influences of other culture are concerned. These factors are commercialization, the influence of tourism that determines it as an attraction, globalization [6], exploitation of culinary heritage tradition $[7,8]$, and modernization of culinary techniques and preparation [9]. In the Philippines, there are culinary traditions that began to be forgotten. For instance, Bacalao is a traditional codfish stew in the province of Cavite. It is traditionally cooked and served during Holy Week especially on Good Friday [10]. This is being prepared because of the Catholic tradition of not eating meat especially pork during the Holy Week. Due to the complexity of the cooking procedure and the perspective of the local community in modernization (e.g., fast food ideology), instead of cooking the dish and its effect of development in the environment that affects the flora and fauna, which are considered to be the raw materials of the culinary tradition, the tradition of cooking Bacalao began to be forgotten. It is one of the many examples of the forgotten Philippine culinary traditions that most of the millennial communities do not know.

This study aims to answer the question on how is pancit significant in the Philippine culinary heritage specifically on its historical, culinary, agricultural, aesthetic, economic, health, spiritual, social, and symbolical aspects. To support the answer from the general research question/gap, the following are the specific questions/gaps: what are the different kinds of pancit available in Luzon as part of the local communities culinary traditions?; how do the different kinds of pancit differ specifically from the raw ingredients, sources, and selling points; cooking materials and equipment; process of cooking and consumption; and the recycling and disposal of waste?; and what are the perspectives of the stakeholders on the culinary heritage significances of pancit specifically on its historical, culinary, agricultural, aesthetic, economic, health, spiritual, social, and symbolical aspects?

\section{Pancit: influence of the Chinese in Philippine noodles}

Pancit (or spelled as pansit) is a Filipino version of a noodle dish that was contributed by the Chinese traders during the pre-Hispanic times of the Philippines. Every part of the Philippine archipelago has its own version of pancit. The basic ingredients include a kind of noodle (bihon, canton, miki, etc.), vegetables (carrots, cabbage, baguio beans, and the like), and meat then seasoned with soy sauce (as a substitute of salt) and pepper.

Before the Spaniards arrived in the Philippines, many historians believe that early Filipinos already started to create small communities, and there was a well-established coordination with different countries for maritime trade and commerce [11-16]. Different products and services were introduced to the Indios (early Filipinos) with the latter exchanging some local products. As it continued, there was a 
positive impact of cross-cultural exchange. Foreign traders learned something from the native culture and vice-versa. The cultural exchange could be related to arts, sciences, linguistics, design, belief, methodologies, religion and governance, and even in culinary activities.

One of the most influential traders, the Chinese or as the Spaniards called them Sangleyes-came from the words hiang and lay, which means, "travelling merchants." Other accounts would say that it came from chiang and lai, which means "regularly come" [17]. Trading with China started in the tenth century $[13,14$, 18 ] or in the eleventh century but "it is conjectured that undocumented trade may have started even two centuries earlier" [1]. To prove it, trade pottery excavated in Laguna, for example, included pieces dating to the Tang Dynasty (A.D. 618-907) [1] that came from the Fujian Province [19].

It is believed that the early Chinese traders came from the Southern part of mainland China based on the archaeological findings discovered by Dr. Arturo de Santos and Dr. Henry Otley Beyer [13]. It was also believed that the first area where the Chinese set foot in the Philippines was in $M a^{\prime} I$ [14]; an ancient sovereign state, which was mentioned in Volume 186 of the Song Dynasty Annals, to have been a part of the "luxurious Chinese foreign trade in the tenth century" [14]. Previously, it was known to be Northern Mindoro [15] but newer findings indicate that $M a^{\prime} I$ was an ancient settlement in the province of Laguna particularly Bay (Ba'I) [14]. When it comes to trade and commerce, the Chinese established regular contact with Sulu [16] in the southern part of the Philippines then also penetrated the northern part especially Tondo and Ylocos. Some of the goods and products brought by the Chinese were coriander, chili, lemon grass, turmeric, shrimp paste, peanut, scallions, soy sauce, cumin, basil, carom seed, tamarind pulp, cinnamon, and black pepper. There were also anglit (small Chinese clay cooking pot) and banga (low earthen jar for storage or cooking). They also contributed some cooking tools and materials for cooking pancit such as karajay, kawali, and kawa (all metal wok-like cooking pans); kalan (stove), and siyansi (kitchen turners). Most of those goods and products were used for cooking.

One major contribution of the Chinese traders was the Filipino-style noodle, which is the pancit; together with the terminology used for the place where people can purchase it, panciteria. Pancit came from two words; pan which means "to cook rice or make noodles" and sit, referring to "food" or a "meal" [20]. Pancit is a noodle dish flavored with seafood and/or meat and/or vegetables [1]. Most of those well-known panciterias in the country during the trade and colonization periods were located in the district of Binondo and Tondo in Manila [20]. The place is also known as the location of the oldest Chinatown in the world dated 1594 (unformal type). There are some evidences of this historical culinary contribution from China. One of these is a testimony appearing in the docketed papers on a consequence of a Royal Resolution in the re-admission of the Chinese to the Philippine islands dated 25-29 October 1779.

"In 1779, 898 Chinese Christians arrived and joined earlier immigrants to the Philippines. Among them were 66 sugar manufacturers, 47 oil manufacturers, 25 pork dealers, 19 wine traders, 15 NOODLE MAKERS, 13 vegetable dealers, 9 PANSIT MAKERS, 6 tahu makers, 3 milk dealers, 3 sweetshop dealers, 2 butchers, 2 water carriers, 1 baker, 1 confectioner, 1 keeper of eating house."

Another evidence of pancit in the Philippine historical records is from Jose Rizal's El Filibusterismo. In Kabanata (chapter) 25: Tawanan at Iyakan (Laughter and Tears), the setting of the story was in Panciteria Macanista de Buen Gusto (Macao Good Taste Restaurant) in Binondo. It was pancit which the characters were eating, and it was described by Rizal as a soup "made with mushrooms, prawns or shrimp, beaten egg, rice noodles, chicken and God knows what else!" [21].

Pancit in the Philippines has a number of variations based on its regional identity. It is the same with the western foreigners in terms of their pastas. Pancit is a general term for the noodles used; then, different places have their different styles of cooking and ingredients. There is a typical pancit that is stir-fried with the choice of meat or seafood, vegetables, and with its seasonings and flavorings. Typically, Filipinos have Pancit BihonGuisado, Pancit Canton, or Pancit Sotanghon. There is also a pancit with a sauce such as Pansit Luglug and Pancit Malabon where it is flavored with katas ng hipon (shrimp juice) and tinapa (dried fish). There are also noodles that are soup-based. It is cooked in a stock or broth just like mami or lomi. Like pasta, it does not mean that the noodles must be in desirable shapes just like Pansit Molo from the municipality of Molo in Iloilo (now a district of Iloilo City). Most of the noodles (as the raw ingredient) available in the market are dried, but for other areas like in the Cagayan region, they use fresh noodles like Pancit Batil Patong and Pancit Cabagan. The processes of making the fresh noodles of the Filipinos are likely the same with what the Chinese are using.

Generally, the variations of pancit are based on the indigenous or available raw materials (e.g., meats and vegetables) of an area. In Malabon, where the community relies on its fishing industry, their Pancit Malabon has a rich seafood flavor.

The Chinese also introduced how noodles can be a source of income for the people by means of panciterias. 
Pancit was first brought to the commercial market by the different Chinese chow-chow vendors (small time stores) [20]. Then they came up with the panciteria, a Spanish-influenced term. The suffix -ria means a place where one can have such an item. For example, cervezeria, panaderia, chocolateria, or noodle houses [22]. A typical panciteria was described in Filipinas y sus habitants, lo que son y lo que deben ser by R. Gonzalez y Martin in 1898 and the researchers quote:

"I could not overcome the repugnance caused by the odor and appearance of the various mincemeats. Orders arrived in an infinity of small plates of porcelain or china similar to demitasse saucers; all food was set out at once on the table or on the floor - usually eight, twelve or more kinds per table." (p. 224)

Some of the most famous panciterias in the Philippines are Panciteria Antigua, which is one of the first in the country; Nueva, Ilang-ilang, Rice Bowl, Siki, and San Jacinto, which were then followed by other panciterias during the American period [20]. Until today, many panciterias are continuously being developed in every part of the archipelago especially in areas with prominent types of pancit. Some of those areas are Binondo in Manila, Tuguegarao City in Cagayan for Pancit Batil Patong, Cabagan in Isabela for Pancit Cabagan, Lipa City in Batangas for Lomi, Malabon for Pancit Malabon, Cavite City in Cavite for Pancit Choko en su Tinta, Quezon Province for Pancit Habhab, Bicol region for Pancit Bato, La Paz in Iloilo for La Paz Batchoy, and Molo in Iloilo for Pancit Molo [22].

Commercialized styles of pancit are also offered to the market. The producers now offer instant Filipino-style noodles that are also available in other Asian countries like China, Japan, and South Korea. Brands like "Lucky Me," "Nissin Yakisoba," and "Quickchow" are some of the examples of today's Filipino-style instant pancit canton. Because of this, different flavors of instant pancit are now introduced to the market those make the dish more experimental to taste. This is also very affordable which is around 10 to 12 Philippine pesos based on the suggested retail price [23]. Issues in terms of its health benefits must be considered when eating this kind of instant noodles. Research shows that it has high content of sodium that is not good for people with hypertension and with kidney problems [24].

\section{The exchange: early Sino-Filipino trade relations}

The Philippines, the home of the world's oldest Chinatown, is also one of the most notable trade partners of China back in the day. In fact, the most common traders during the pre-colonial Philippines were the Chinese.
The advent of trade between China and the Philippines started even before the Sung Dynasty. During the T'ang (Thang) dynasty China (seventh to the ninth century AD), the two peoples of China and the Philippines already had relatively close relations and material as well as cultural exchanges. According to Chinese records, Filipinos went to China before the Chinese came to the Philippines [25].

Academicians and researchers believes that Arab traders during the Sung Dynasty (960-1127 AD) delivered goods from the Philippines to the port of Canton in the southwestern part of China [25]. This economic relation created the establishment of Chinese posts in the coastal towns of the Philippines where the imports from the mainland China is brought. The Chinese exchanged silk, colored glass, tortoise shells, porcelain, beads, and even influenced the early Filipinos in their cuisine by introducing their own. These trades started when a certain Chinese geographer of the thirteenth century Chao Ju-Kua wrote the barter trade between them and the natives of Mindoro, an island southwest of the mainland Luzon.

The Chinese became the dominant traders in the twelfth and thirteenth centuries during the Sung Dynasty (960-1279 AD). Prior to 1225, Chinese vessels were making regular trading-trips to nearly all parts of the Philippines and many places are mentioned in the records, but descriptions are given of only a few. Apart from Sulu, which has always maintained closer relations with Borneo than with the northern Philippines, the most important trade-center appears to have been Mindoro, which was mentioned as such in the tenth century [26].

\section{Recent discoveries: more than silk and silver}

It was revealed that kamote (sweet potato) along with tobacco were also introduced into China during the galleon trade between the East and West coasts of the Pacific from Manila to Acapulco, Mexico in the sixteenth century [27]. The introduction of kamote came in late 1500 s to Fujian province by an overseas Chinese from Changle, Fujian province, trading in Luzon. The local kamote was drought-tolerant, high-yield, and typhoon-resistant. This brought a huge impact on China because it fed numerous people at the time when the Ming Dynasty experienced abnormal weather conditions and famine due to food shortage. People relied on kamote to satisfy their hunger, and since then, kamote was cultivated across China as a major crop [27].

Besides kamote, during the Galleon Trade era, the silver dollars brought into China through the Philippines were about 200 million pesos. A large amount of silver dollar input was beneficial to the Chinese social and economic development [27]. "The long-standing and well-established friendly exchange between China and Philippines generates huge influence on the economic and cultural development of both countries" [27]. 
During Wu's visits to the Philippines to conduct research, he believes that there had been proof that China and the Philippines first built their relationship through trading. Chinese merchants participated in two kinds of markets: the traditional area market, providing merchandise to Luzon's indigenous peoples; and the contemporary world market, which was to provide merchandise to the Spanish who transported and sold them to the American and European markets [27]. added that "The trade volume of the latter (contemporary world market) was huge. Hence, Luzon and its surrounding islands became a significant part of the world market."

Browsing the early literature strongly supports the belief of the researchers that the Philippines, specifically Luzon island, was once upon a time the main focus of the Chinese traders which eventually after centuries of trade, influenced the Luzon inhabitants in many ways, including the Filipinos' affinity with noodle dishes.

\section{Luzon: its historical and geographical entity}

Among the three primary island groups in the Philippines, Luzon is considerably extensive becoming the most important island of the country where Manila, also situated here, is the seat of government and major metropolis. This large island is roughly rectangular in shape as Manila lies north while two peninsulas (Batangas and Bicol) protrude south and southeast, giving Luzon its irregular shape.

It is in the northern part of the Philippine archipelago where Luzon is located, surrounded by the Luzon Strait (north), Philippine Sea (east), Sibuyan Sea (south), and South China Sea (west). More than 3000 miles long, Luzon's coastline is indented by several prime bays and gulfs including Lingayen Gulf and Manila Bay (west), and Lamon Bay and Lagonoy Gulf (east). The land area of the Philippines is mainly occupied by Luzon since it represents about one-third of the total area of the country. Four hundred sixty by one hundred forty miles is its greatest dimensions [28] (Fig. 1).

There is a predominant north-south trend in its rivers and relief features. The most important ranges of the country can also be found in Luzon such as the Cordillera Central (north), the Sierra Madre (east coast), and the Zambales Mountain (central-western coast). Moreover,

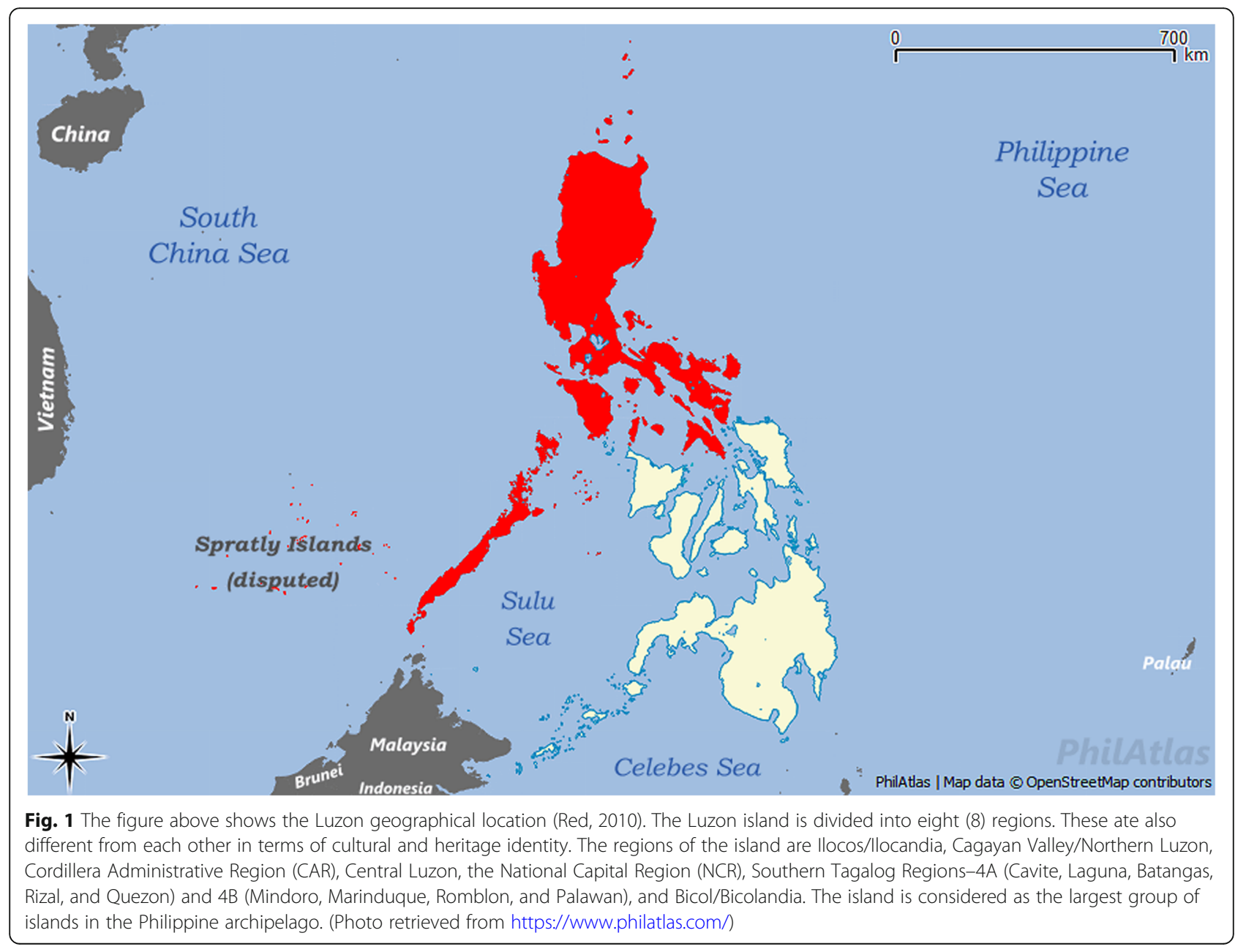


found between the provinces of Benguet and Nueva Vizcaya is Mount Pulag which is the island's highest peak at $9612 \mathrm{ft}$. above sea level. While in Bicol Peninsula, Mayon Volcano stands nearly perfect at $8077 \mathrm{ft}$. Mayon Volcano is recognized to be among the isolated volcanic cones in the country and is still active. When it comes to lakes, the Taal Lake and Laguna de Bay is equally important in Luzon. In addition, Cagayan, Abra, Agno, Pampanga, and Bicol are the major rivers in this island.

Luzon leads the country both in industry (concentrated near Manila) and in agriculture (rice, corn, coconuts, sugarcane, mangoes, bananas). The major grain-producing region is the central plain extending one hundred miles north of Manila. The glorious Rice Terraces of the Ifugao mountaineers can be discovered when going farther north. Bondoc and Bicol peninsulas possess extensive coconut plantations. Iron, gold, manganese, and copper are excavated. Forest areas provide excellent hardwoods [28].

In addition to Manila as the Nation's capital, the main cities are Quezon City, Pasay, Cabanatuan, Legaspi, Baguio, Batangas, and Laoag. More than half of the Filipino population lives in the island of Luzon with its area having 40,420 $\mathrm{mi}^{2}$ and its population counting 57,470,097 in adjoining islands.

Luzon, being the largest island, has played a major role in the nation's history. Manila harbor has been important since the arrival of the Spanish in the late sixteenth century. At that time, Manila Harbor has been a significant topic in the history of the Philippines. It was in Luzon where the revolt against the Spanish rule began (1896), when U.S. forces struggled over control of the islands from Spain (1898), and when the Philippine Insurrection broke out due to the opposition to U.S. rule (1899). Japanese forces took over several places on 10 December 1941 and in early 1942, the Allied forces made their last stand in Peninsula and Corregidor. Luzon was recovered in 1945 after a major landing from Lingayen Gulf (January), a bloody fight for Manila (February), and a protracted mop-up operation, which were not completed until June. Between 1971 and 1992, many U.S. military bases of the island were closed down to some extent due to the devastation caused by Mt. Pinatubo's eruption; the one at Subic Bay was converted to a free-trade zone [29].

\section{Method \\ Design}

This research used the qualitative method, which focused on assessing and analyzing the perspectives and opinions of the stakeholders. The researchers highlighted the identification of different heritage research evidences specifically on the physical, oral, documentary, or archival types. For each heritage evidences, the following research tools were used (Table 1):

\section{Subject and study site}

For the subject area and material of the research, the researcher focused on the geographical scope of the Luzon Island specifically places that have existing, emerging, and potentially known pancit. The basis for determining the sites was from the available primary and secondary references, local and national culinary historians, and promotional materials from different tourism-based offices (national, local, and NGOs) that highlight pancit as their primary or secondary tourism product and local culinary identity.

The researchers concentrated on the following regions: Region 1: Ilocos Region (Ilocos Norte and Ilocos Sur); Region 2: Cagayan Valley/Northern Philippines (Cagayan and Isabela); Region 3: Central Luzon (Pampanga, Bulacan, Bataan, Tarlac, and Nueva Ecija); Region CAR: Cordillera Administrative Region (Abra); Region NCR: National Capital Region (Muntinlupa City, Pasay City, Makati City, Pasig City, City of Manila, San Juan City, Quezon City, Marikina City, and Malabon City); Region 4A: CaLaBaRzon (Cavite, Laguna, Batangas, Rizal, and Quezon); Region 4B: MiMaRoPa (Marinduque, Romblon, and Palawan); and Region 5: Bicol Region (Camarines Sur and Albay)

Table 1 The table shows the tabular summary of the research evidences and tools as aligned to the theoretical frameworks. The table highlights that the evidences are divided into three major groups: physical, oral, and documentary/archival. Each group of evidences hast its research tools and materials/instrumentation. All of the process on how to gather the needed information are based from the theoretical frameworks used in the international and national perspectives. These frameworks are also used to different researches published that concentrates on food and food heritage (conceptualized by the authors)

\begin{tabular}{|c|c|c|c|}
\hline Research evidence & Research tools & Research materials & Alignment to the theoretical frameworks \\
\hline Physical & Observation and documentation & $\begin{array}{l}\text { Documentation template } \\
\text { for culinary heritage } \\
\text { (see attachment) }\end{array}$ & $\begin{array}{l}2003 \text { UNESCO Convention for the Safeguarding of } \\
\text { Intangible Cultural Heritage [3], Australia ICOMOS } \\
\text { Burra Charter for Places of Cultural Significance [30], } \\
\text { Republic Act No. } 10066 \text { [31], and the Culinary } \\
\text { Mapping [32] }\end{array}$ \\
\hline Oral & In-depth interview & Questionnaire (see attachment) & $\begin{array}{l}2003 \text { UNESCO Convention for the Safeguarding of } \\
\text { Intangible Cultural Heritage [3] }\end{array}$ \\
\hline Documentary/archival & $\begin{array}{l}\text { Readings from primary and } \\
\text { secondary references }\end{array}$ & $-0-$ & $\begin{array}{l}\text { Australia ICOMOS Burra Charter for Places of Cultural } \\
\text { Significance [30] and the Culinary Mapping [32] }\end{array}$ \\
\hline
\end{tabular}




\section{Data measure}

The details of the different research tools used in the research were observation and documentation-this research tool determined different details and concepts of pancit by observing it as a common lifestyle of the local community and documenting it based on the theoretical frameworks. The researchers observed the following details: the raw ingredients and its sources and selling points, cooking materials and equipment, process of cooking and consumption, and the recycling and disposal of waste. For the documentation of the culinary tradition, the researchers used a template that was based on the concepts of heritage documentation from the policies of the National Commission for Culture and the Arts (NCCA) [33], Cultural Mapping by the University of Santo Tomas Graduate School-Center for Conservation of Cultural Properties and the Environment in the Tropics (USTGS-CCCPET) [34] and the Culinary Mapping template in a town or barangay [32]; In-depth Interview-this is a qualitative type of research that seeks to determine a comprehensive in-sight from a person with the condition of having only a small group of respondents [35]. This established the perspectives of the stakeholders specifically the Local Government Units (LGUs), local culinary historians, owners of the restaurants or people who are known for practicing the culinary tradition, and, if applicable, Non-Government Organizations (NGOs) who are managing and/or safeguarding the culinary tradition on the culinary heritage significance as an intangible cultural property of the community and how it helps them in their lifestyle; and Readings from Primary and Secondary References-as part of any heritage and cultural research, tedious archival, and documentary work were required. This was the basis for the theoretical and conceptual frameworks for the implementation of the research.

Data collection procedure and ethical consideration (Fig. 2) As for the research information gathering procedure, the researcher focused first on the assessment and analysis of different primary and secondary references such as books, journal articles or other related references. Then, for ethical standards, the researcher distributed appropriate letters of intent to different stakeholders and waited for their approval before the execution of the research fieldwork. After the approval, research fieldworks were done specifically on the observation and documentation of the culinary tradition; and in-depth interviews were conducted to different stakeholders. After the fieldwork, an assessment and analysis of the findings and data gathered was completed.

\section{Mode of analysis/data explicitation}

The gathered information will be analyzed by means of repertory grid and thematic analysis. The mode of analysis for the research was based on the following indicators/dimensions (Table 2):

\section{Findings and discussions}

Sari-sari: findings from the culinary heritage documentation of Philippine noodles in Luzon (Fig. 3)

The researchers completed the project by examining the eight regions of Luzon Island as the main focus and the limitation of the study. These regions are considerably abundant with a fusion of diverse background and ethnicity that shaped their cultural landscape and culinary prowess and identity. In the 20 provinces, 27 cities, and 26 municipalities, an impressive total of 101 pancit

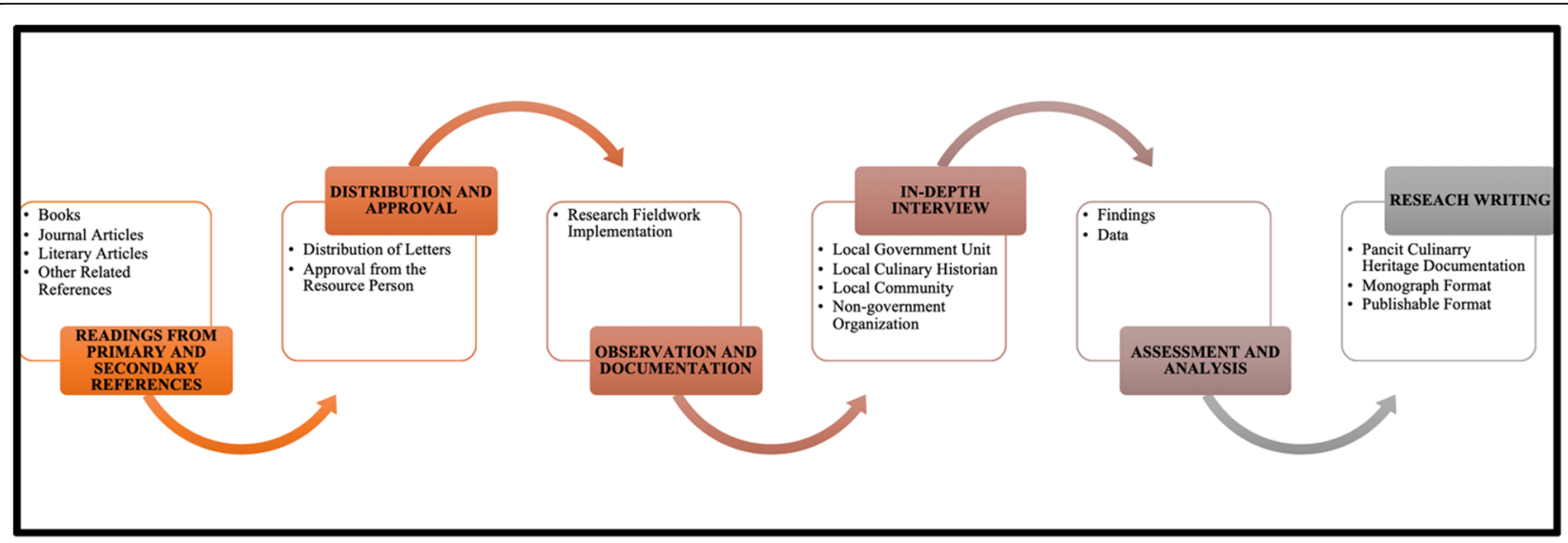

Fig. 2 The figure above shows the data gathering procedure of the research. This also highlights the significance of implementing ethical consideration in the conduct of the research fieldwork. The procedure is divided into six parts. These are readings from primary and secondary references; distribution and approval; observation and documentation; in-depth interview, assessment and analysis; and research writing. The procedure was based from the implementation of the research and its related processes. (conceptualized by the authors) 
Table 2 The table below shows the indicators/dimensions for the research. These indicators/dimensions were used to analyze the information gathered. The indicators/dimensions are divided into two: culinary heritage documentation and significance. Each indicator/dimension identifies a specific aspect in the development of the research. It is also based from different theoretical and conceptual frameworks published on food and food heritage. (conceptualized by the authors) Culinary heritage documentation
Raw ingredients-this determines the local produce and
processed/manufactured resources that will be used to come-up a dish.

\section{Sources of the raw ingredients - this identifies the sources of the raw ingredients either in the agricultural or manufacturing process.}

Selling points of the raw ingredients - this highlights the availability of the raw ingredients to the general public by determining the market selling points either in a formal or informal way.

Cooking materials and equipment-this identifies the materials and equipment that are used to cook the dish. This can be under the traditional or from the modern concepts that are used by the local community.

Process of cooking - this determines the way on how to cook the dish using different technical or traditional process of cooking.

Consumption - this highlights the way on how the local community eats and consumes the dish based from their lifestyle and culture.

Recycling and disposal of waste-this identifies the practices of the local community on how to dispose and recycle food waste and other related materials to measure the environmental sustainability.
Culinary heritage significance

Historical significance - this determines the story of pancit based from the available physical, oral, archival, and/or associated evidences. The story can be related from the pre-Hispanic, Spanish, American, Japanese or the Third Republic, which will relate to the existence of the culinary tradition in a particular area.

Culinary significance - this identifies the attachment of the food to the everyday lifestyle of the community and other people associated. Proper recipe standards, raw ingredients, process of cooking, and food service are related.

Agricultural significance - this determines the relationship of the culinary tradition to the agricultural landscape, produces, and process anchored in the raw ingredients and materials used to cook the dish.

Aesthetic significance-this pertains to the physical consistency and appearance of the dish especially related to the way on how raw ingredients are combined and on how the dish is being plated in the desired serving utensils. The proper way of eating the food is also included, which is influenced by the local community.

Economic significance - this determines the positive effects of the culinary tradition in the growth of a particular area for uplifting the lives of the community and contributing to the total production of goods and services offered

Health significance-this determines the relationship of the culinary tradition to the required nutritional value especially for consumption.

Spiritual significance-this highlights the significance of the culinary tradition to the religious and spiritual aspects of the local community.

Social significance - this relates the culinary tradition to important events related to the area and to its local community. This is also discussing what the local community's perspective about the culinary tradition as it is part of their everyday lifestyle

Symbolical significance - the culinary tradition is being interpreted as part of the local community's morals, values, and ethical practices. dishes were mapped and further explored for their wellknown and significant variety from soup-based dishes, stir-fried local favorite, down to the least-known, exotic, and unique kind prepared and served for different occasions.

This fascinating affinity of Filipinos for pancit is manifested in a number of ways. Each region, province, city, and municipality is uniquely deviated from each other (e.g., from the main ingredients to the manner of preparation and consumption). These discoveries in the conduct of this project allowed the researchers to have a substantial understanding of the subject and confirmed prior assumptions (Fig. 4).

Table 3 presents the total number of pancit dishes per region highlighting the National Capital Region (NCR) as the home of the highest number of pancit documented. This was evident because of the strong influence of the
Chinese community, which developed the first China town in the world in 1594 [12].

The 20 provinces that were visited enumerated in Table 4 shows the names of the pancit dish with a corresponding ranking per province. The following provinces have evident Chinese communities that were developed through time by means of early trading and commerce; migration and exploration for new opportunities [36]. It matches the observation of the researchers based on the mapped pancit dishes as part of their influences and also the context of putting-up businesses like panciterias.

The summary of pancit dishes per province in Table 4 revealed the highest number of pancit documented. Cavite ranks first; Bulacan came second; and Bataan, Camarines Sur, and Laguna placed third overall. A total of 56 pancit dishes were documented within the Luzon Region. 


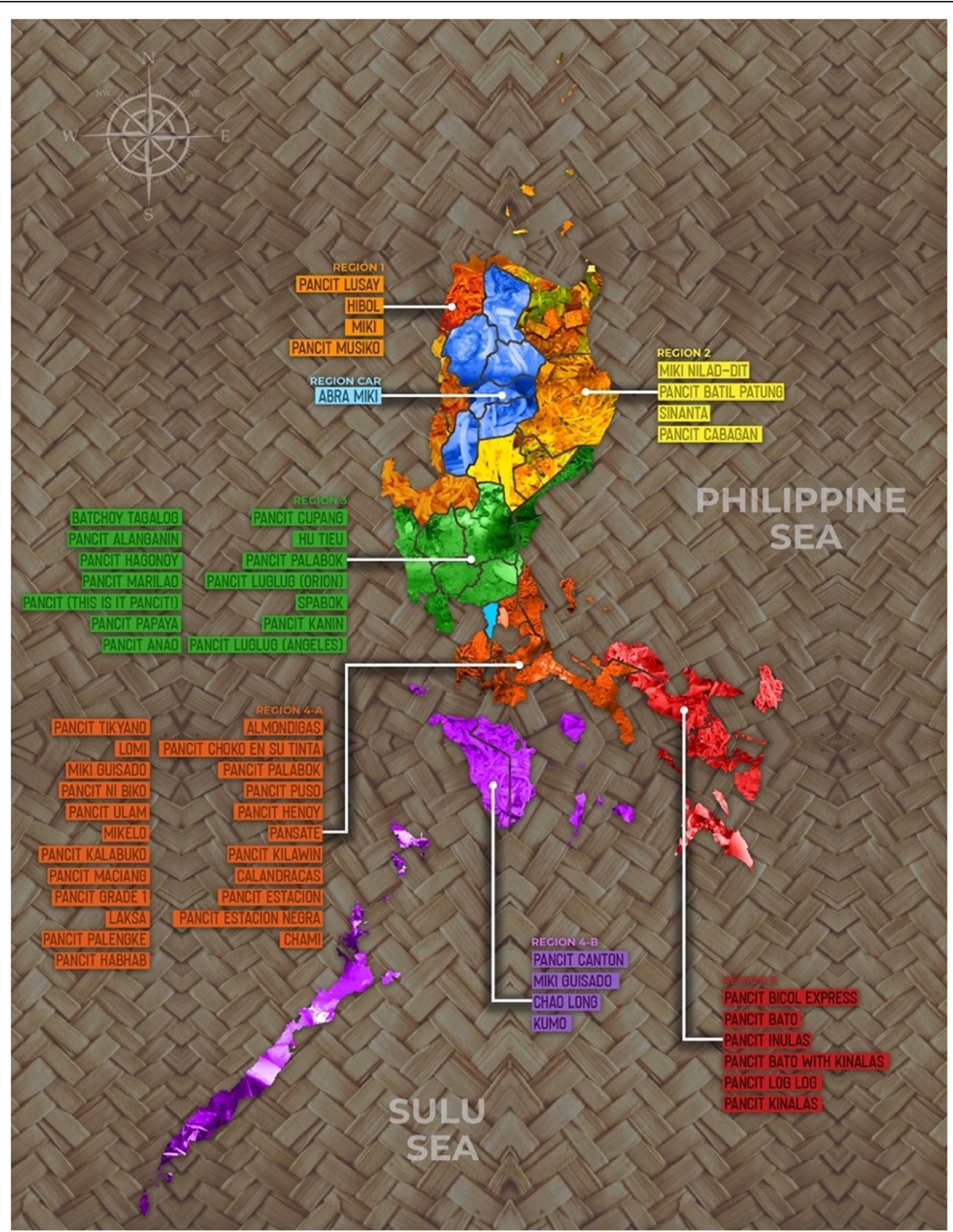

Fig 3. The figure above represents the summary of the Ysla de Panciteria Documentation Project in Luzon Island, Philippines. The map of Luzon Island is divided into eight regions. It also highlights the documented pancit dishes. The availability of the pancit dishes were based from the evidences identified in the research. There is a total of one hundred and one pancit dishes. (photo from the authors)

The 27 cities that were visited as shown below present the names of the pancit dishes with a corresponding ranking per city.

Table 5 provides the summary of pancit dishes per city, highlighting the greatest number of pancit documented. The City of Manila was declared first in rank, Cavite City, second; and Malabon City and Muntinlupa City came in third overall. The overall total of pancit documented is 74 .

The 26 municipalities were visited as shown below indicates the names of the pancit dish with a corresponding ranking per municipality.
Based on Table 6, out of 33 pancit dishes documented, Nabua, Camarines Sur, and Tanza, Cavite ranked first, Bocaue, Bulacan; Orani, Bataan; and Pagsanjan, Laguna, second, and the rest in the list came in third overall.

In the history of the said provinces, cities, and municipalities, these areas are evident in the context of Chinese migration, along with commerce and trading that influences the cultural environment of the communities. Both Cavite and Camarines Sur, for instance, were known as focal points for trading and commerce especially coming from Mainland China specifically from $\mathrm{Fu}$ jian and Canton provinces [37, 38]. The cities of Manila 


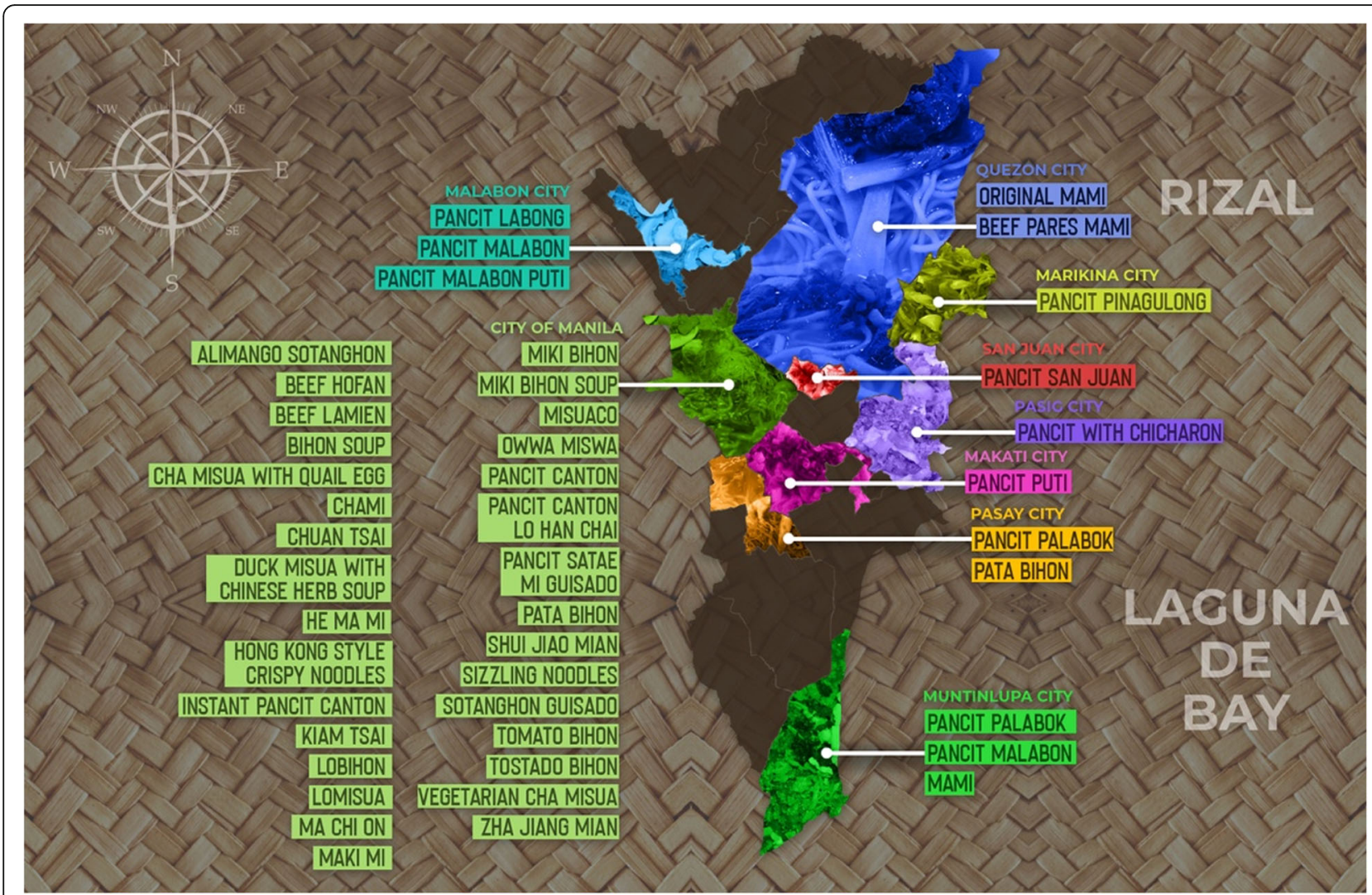

Fig. 4 The figure above shows the representation of the Ysla de Panciteria Documentation Project in the National Capital Region (NCR). NCR is considered as having the highest number of pancit dishes with 45 . Among all the cities and municipality in the NCR, City of Manila got the highest number with 31. This is evident because of the presence of the oldest Chinatown in the World. All figures were based from the conducted research fieldwork. (photo from the authors)

Table 3 The table below shows the summary of the regions and its corresponding number of pancit dishes in Luzon Island. The greatest number of pancit dishes came from the National Capital Region (NCR). The second highest number came from CaLaBaRzon region with 23 pancit dishes. The lowest number of pancit dishes came from the Cordillera Administrative Region (CAR) with one pancit dish. All figures were based from the conducted research fieldwork. (conceptualized by the authors)

\begin{tabular}{ll}
\hline Regions in Luzon & Number of pancit \\
\hline Region 1: llocos Region/llocandia & 4 \\
Region 2: Cagayan Valley/Northern Philippines & 4 \\
Region CAR: Cordillera Administrative Region & 1 \\
Region 3: Central Luzon & 14 \\
Region NCR: National Capital Region & 45 \\
Region 4A: CaLaBaRzon & 23 \\
Region 4B: MiMaRoPa & 4 \\
Region 5: Bicol Region/Bicolandia & 6 \\
Total & 101 \\
\hline
\end{tabular}

and Malabon became areas that most of the Chinese and Filipino-Chinese communities resided in and created their residential entities [12, 39]. Not all areas are considered to be historically aligned as Chinese migration and commercial center. For some, the local community was influenced by their friends, relatives, and even workers who are Chinese. This is evident to most of the panciteria owners in the areas that were influenced by the Chinese migrants in the Philippines especially on food menu and business [40].

\section{Proseso: process and characteristics of Philippine noodles in Luzon}

Aside from nourishing human's physical entity and its related nutritional contribution, food is an important cultural entity of the community $[41,42]$. As an identity of the community, its process and characteristics are developed due to their practices, traditions, and culture. Whether it is indigenous or foreign-introduced culinary heritage, it is developed and completely immersed to the community, which is considered as part of their cultural environment. 
Table 4 The table below shows the summary of provinces, corresponding number, name of pancit and its ranking. There are twenty provinces in the Island. Among the provinces, Cavite got the highest number with ten dishes. The province of Cavite is influenced through its historical and cultural context. The provinces having the lowest number of dishes are Abra, Albay, Ilocos Sur, Isabela, Nueva Ecija, Palawan, Pampanga, Romblon, and Tarlac. (conceptualized by the authors)

\begin{tabular}{|c|c|c|c|}
\hline Rank & Name of the province & Number of pancit & Name of the pancit \\
\hline \multirow[t]{10}{*}{1} & Cavite & 10 & Pancit Henoy \\
\hline & & & Almonigas \\
\hline & & & Pancit choko en su tinta \\
\hline & & & Pancit Palabok \\
\hline & & & Pancit Puso \\
\hline & & & Pansate \\
\hline & & & Pancit Kilawin \\
\hline & & & Calandracas \\
\hline & & & Pancit Estacion \\
\hline & & & Pancit Estacion Negra \\
\hline \multirow[t]{6}{*}{2} & Bulacan & 6 & Batchoy Tagalog \\
\hline & & & Pancit Alanganin \\
\hline & & & Pancit Hagonoy \\
\hline & & & Pancit Marilao \\
\hline & & & Pancit (This is it Pancit!) \\
\hline & & & Pancit Papaya \\
\hline \multirow[t]{15}{*}{3} & Bataan & 5 & Pancit Cupang \\
\hline & & & Hu Tieu \\
\hline & & & Pancit Palabok \\
\hline & & & Pancit Luglug \\
\hline & & & Spabok \\
\hline & Camarines Sur & 5 & Pancit Bato \\
\hline & & & Pancit Bato with Kinalas \\
\hline & & & Pancit Inulas \\
\hline & & & Pancit Log Log \\
\hline & & & Pancit Kinalas \\
\hline & Laguna & 5 & Pancit Ulam \\
\hline & & & Pancit Kalabuko \\
\hline & & & Pancit Maciang \\
\hline & & & Pancit Grade 1 \\
\hline & & & Mikelo \\
\hline \multirow[t]{4}{*}{4} & Batangas & 4 & Pancit Tikyano \\
\hline & & & Lomi \\
\hline & & & Miki Guisado \\
\hline & & & Pancit ni Mang Biko \\
\hline \multirow[t]{6}{*}{5} & Cagayan & 3 & Miki Nilad-dit \\
\hline & & & Pancit Batil Patong \\
\hline & & & Sinanta \\
\hline & llocos Norte & 3 & Miki \\
\hline & & & Hibol \\
\hline & & & Pancit Lusay \\
\hline 6 & Marinduque & 2 & Pancit Canton \\
\hline
\end{tabular}


Table 4 The table below shows the summary of provinces, corresponding number, name of pancit and its ranking. There are twenty provinces in the Island. Among the provinces, Cavite got the highest number with ten dishes. The province of Cavite is influenced through its historical and cultural context. The provinces having the lowest number of dishes are Abra, Albay, llocos Sur, Isabela, Nueva Ecija, Palawan, Pampanga, Romblon, and Tarlac. (conceptualized by the authors) (Continued)

\begin{tabular}{llll}
\hline Rank & Name of the province & Number of pancit & Name of the pancit \\
\hline & Quezon & 2 & Miki Guisado \\
Pizal & Pancit Habhab & Chami \\
& & 2 & Laksa \\
& Abra & 1 & Pancit Palengke \\
7 & Albay & 1 & Abra Miki \\
& Ilocos Sur & 1 & Pancit Bicol Express \\
& Isabela & 1 & Pancit Musiko \\
& Nueva Ecija & 1 & Pancit Cabagan \\
& Palawan & 1 & Pancit Kanin \\
& Pampanga & 1 & Chao Long \\
& Romblon & 1 & Pancit Luglug \\
Tarlac & 1 & 1 & Kumo \\
\hline
\end{tabular}

In the culinary context of Luzon Island pancit dishes, the following sub-chapters discussed the overview of its process and the characteristics based on its raw ingredients, sources, and selling points; cooking materials and equipment; process of cooking, consumption, and recycling and disposal of waste:

\section{Raw ingredients}

With regard the raw ingredients used for pancit dishes in Luzon Island, there are different factors that influence the community to develop and provide appropriate ingredients for their own versions and varieties. These factors are foreign or local influencer; availability of local resources; provision of getting the ingredients from the main or known suppliers; skill-based development of the community; influence of modernization and technology; and alternative resources.

Most of the pancit dishes in Luzon Island are influenced by different foreign communities either it is directly or indirectly introduced to the community. With this, ingredients are also influenced by the influencers and were adopted by the community. For instance, $\mathrm{Hu}$ Tieu of Morong, Bataan, and Chao Long of Puerto Princesa City, Palawan, are both introduced by the Vietnamese refugee communities. To preserve its integrity, the Vietnamese refugee communities also introduced the typical ingredients for cooking it such as mint leaves, Vietnamese rice noodles, and bean sprouts.

But even though foreign influencers introduced the ingredients, not all of them are locally available. From this context, the community responded by introducing local resources that can be used. This makes the foreignculinary heritage localized based on the available resources of the community. For instance, typical palabok-based pancit uses chicharron as one of the toppings to provide added texture and flavor. But in Marilao, Bulacan, Pancit Marilao is iconic for its crunchy toppings, which is crushed glutinous rice okoy. It was used because the community and their area are known as one of the agricultural centers in the province especially by producing rice grains.

Some of the ingredients used by the community are produced or provided by certain individuals or groups of people. They can be located within or outside the community. This is being done by most of the members of the community because they already know the quality of the products or historically, they are known for providing a certain ingredient. For instance, Balay Cena Una in Daraga, Albay, who is known for their Pancit Bicol Express, only purchases their miki noodles at Palamigan, Daraga Public Market.

For most of the producers of pancit dishes, they are also known for producing their iconic ingredients such as their noodles and toppings (e.g., kikiam). This developed the culinary skills of the community and sustains the identity of the Culinary Heritage. In Boac, Marinduque, Chi Wing's Canton Panciteria produces its own canton noodles, in which its recipe was passed down from generation to generation. This was also the case of Lomi from Panciteria de Lipa, Batangas. 
Table 5 The table below shows the summary of the rankings, name of the city, corresponding number, and the name of pancit. There are twenty-seven cities that have pancit dishes in Luzon Island. From those cities, 74 pancit dishes were identified. The City of Manila has the highest number of pancit dishes with 31. There are a lot of cities that have only one Pancit dish (conceptualized by the authors)

\begin{tabular}{|c|c|c|c|}
\hline Rank & Name of the city & Number of pancit & Name of the pancit \\
\hline \multirow[t]{31}{*}{1} & \multirow[t]{31}{*}{ City of Manila } & \multirow[t]{31}{*}{31} & Alimango Sotangon \\
\hline & & & Beef Hofan \\
\hline & & & Beef Lamien \\
\hline & & & Bihon Soup \\
\hline & & & Cha Misua with Quail Egg \\
\hline & & & Chami \\
\hline & & & Chuan Tsai \\
\hline & & & Duck Misua with Chinese Herb Soup \\
\hline & & & He Ma Mi \\
\hline & & & Hong Kong Style Crispy Noodles \\
\hline & & & Instant Pancit Canton \\
\hline & & & Kiam Tsai \\
\hline & & & Lo Bihon \\
\hline & & & Lo Misua \\
\hline & & & Ma Chi On \\
\hline & & & Maki Mi \\
\hline & & & Miki Bihon Soup \\
\hline & & & Miki Bihon \\
\hline & & & Misuaco \\
\hline & & & Owwa Miswa \\
\hline & & & Pancit Canton Lo Han Chay \\
\hline & & & Pancit Canton \\
\hline & & & Pancit Satae Mi Guisado \\
\hline & & & Pata Bihon \\
\hline & & & Shui Jiao Mian \\
\hline & & & Sizzling Noodles \\
\hline & & & Sotanghon Guisado \\
\hline & & & Tomato Bihon \\
\hline & & & Tostado Bihon \\
\hline & & & Vegetarian Cha Misua \\
\hline & & & Zha Jiang Mian \\
\hline \multirow[t]{9}{*}{2} & \multirow[t]{9}{*}{ Cavite City, Cavite } & \multirow[t]{9}{*}{9} & Pancit Henoy \\
\hline & & & Almonigas \\
\hline & & & Pancit choko en su tinta \\
\hline & & & Pancit Palabok \\
\hline & & & Pancit Puso \\
\hline & & & Pansate \\
\hline & & & Calandracas \\
\hline & & & Pancit Estacion \\
\hline & & & Pancit Estacion Negra \\
\hline \multirow[t]{2}{*}{3} & \multirow[t]{2}{*}{ Malabon City } & \multirow[t]{2}{*}{3} & Pancit Labong \\
\hline & & & Pancit Malabon Puti \\
\hline
\end{tabular}


Table 5 The table below shows the summary of the rankings, name of the city, corresponding number, and the name of pancit. There are twenty-seven cities that have pancit dishes in Luzon Island. From those cities, 74 pancit dishes were identified. The City of Manila has the highest number of pancit dishes with 31. There are a lot of cities that have only one Pancit dish (conceptualized by the authors) (Continued)

\begin{tabular}{|c|c|c|c|}
\hline Rank & Name of the city & Number of pancit & Name of the pancit \\
\hline & & & Pancit Malabon \\
\hline & Muntinlupa City & 3 & Mami \\
\hline & & & Pancit Malabon \\
\hline & & & Pancit Palabok \\
\hline \multirow[t]{10}{*}{4} & Pasay City & 2 & Pancit Palabok \\
\hline & & & Pata Bihon \\
\hline & Laoag City, llocos Norte & 2 & Pancit Lusay \\
\hline & & & Hibol \\
\hline & Lipa City, Batangas & 2 & Lomi \\
\hline & & & Miki Guisado \\
\hline & Quezon City & 2 & Beef Pares Mami \\
\hline & & & The Original Mami \\
\hline & Tuguegarao City, Cagayan & 2 & Pancit Batil Patong \\
\hline & & & Sinanta \\
\hline \multirow[t]{18}{*}{5} & Angeles City, Pampanga & 1 & Pancit Luglug \\
\hline & Balanga City, Bataan & 1 & Pancit Cupang \\
\hline & Batac City, llocos Norte & 1 & Miki \\
\hline & Batangas City, Batangas & 1 & Pancit Tikyano \\
\hline & Lucena City, Quezon & 1 & Chami \\
\hline & Naga City, Camarines Sur & 1 & Pancit Kinalas \\
\hline & Makati City & 1 & Pancit Puti \\
\hline & Marikina City & 1 & Pancit Pinagulong \\
\hline & Meycauayan City, Bulacan & 1 & Pancit (This is it Pancit!) \\
\hline & Pasig City & 1 & The Original Pancit with Chicharon \\
\hline & Puerto Princesa City, Palawan & 1 & Chao Long \\
\hline & San Jose City, Nueva Ecija & 1 & Pancit Kanin \\
\hline & San Juan City & 1 & Pancit San Juan \\
\hline & San Pablo City, Laguna & 1 & Pancit Kalabuko \\
\hline & San Pedro City, Laguna & 1 & Pancit Maciang \\
\hline & Sta. Rosa City, Laguna & 1 & Pancit Grade 1 \\
\hline & Trece Martires City, Cavite & 1 & Pancit Estacion Negra \\
\hline & Vigan City, Ilocos Sur & 1 & Pancit Musiko \\
\hline Total & & 74 & \\
\hline
\end{tabular}

Because of modernization and technology, specifically the introduction of machineries and equipment, this affected the production of different ingredients and its related quality standards. At some point, the introduction of modern technology helps the community to commercialize the Culinary Heritage especially for their visitors and tourists. With this, there are certain problems that emerged such as palatability, size, color, and texture. The production of the noodles is the typical example that reflects the effect of modern machineries and equipment. It differs based on the color, the measurement of the strands and even the quality of the noodles especially after cooking it.

Alternative ingredients are also being used by the community especially that most of the ingredients and its related culture are based on foreign entities. Pancit Estacion and Pancit Estacion Negra in the province of Cavite is an example for developing the ingredients using the available resources in the area. Instead of using noodles, they used beans sprouts as an alternative. 
Table 6 The table below shows the summary of the rankings, name of the municipality, corresponding number, and the name of pancit. There are 26 municipalities that have pancit dishes in Luzon Island. From those municipalities, 34 pancit dishes were identified. The municipalities of Nabua in Camarines Sur and Tanza in Cavite have the highest number of pancit dishes with three. There are a lot of cities that have only one pancit dish (conceptualized by the authors)

\begin{tabular}{|c|c|c|c|}
\hline Rank & Name of the municipality & Number of pancit & Name of the pancit \\
\hline \multirow[t]{6}{*}{1} & Nabua, Camarines Sur & 3 & Pancit Bato with Kinalas \\
\hline & & & Pancit Inulas \\
\hline & & & Pancit Log Log \\
\hline & Tanza, Cavite & 3 & Calandracas \\
\hline & & & Pancit Estacion \\
\hline & & & Pancit Estacion Negra \\
\hline \multirow[t]{6}{*}{2} & Bocaue, Bulacan & 2 & Batchoy Tagalog \\
\hline & & & Pancit Alanganin \\
\hline & Orion, Bataan & 2 & Pancit Palabok \\
\hline & & & Spabok \\
\hline & Pagsanjan, Laguna & 2 & Pancit Ulam \\
\hline & & & Mikelo \\
\hline \multirow[t]{21}{*}{3} & Anao, Tarlac & 1 & Pancit Anao \\
\hline & Aparri, Cagayan & 1 & Miki Nilad-dit \\
\hline & Angono, Rizal & 1 & Laksa \\
\hline & Bangued, Abra & 1 & Abra Miki \\
\hline & Bato, Camarines Sur & 1 & Pancit Bato \\
\hline & Boac, Marinduque & 1 & Pancit Canton \\
\hline & Cabagan, Isabela & 1 & Pancit Cabagan \\
\hline & Daraga, Albay & 1 & Pancit Bicol Express \\
\hline & Hagonoy, Bulacan & 1 & Pancit Hagonoy \\
\hline & Kawit, Cavite & 1 & Pancit Henoy \\
\hline & Lucban, Quezon & 1 & Pancit Habhab \\
\hline & Marilao, Bulacan & 1 & Pancit Marilao \\
\hline & Morong, Bataan & 1 & Pancit Palengke \\
\hline & Morong, Rizal & 1 & Hu Tieu \\
\hline & Odiongan, Romblon & 1 & Komo \\
\hline & Orani, Bataan & 1 & Pancit Luglug \\
\hline & Paete, Laguna & 1 & Mikelo \\
\hline & Rosario, Cavite & 1 & Pancit Kilawin \\
\hline & Santa Cruz, Marinduque & 1 & Miki Guisado \\
\hline & Sta. Maria, Bulacan & 1 & Pancit Papaya \\
\hline & Taal, Batangas & 1 & Pancit ni Mang Biko \\
\hline Total & & 33 & \\
\hline
\end{tabular}

Table 7 highlights the summarized ingredients used for pancit dishes in the Luzon Island. The table showcases outstanding ingredients based on the development of the community's culture and its related influences from foreign entities. Included in Table 7 are the frequently used ingredients for most parts in the island of Luzon.

\section{Sources and selling points}

For most of the towns and areas in Luzon, preparing pancit dishes, sources, and selling points of different raw ingredients are an important factor especially on the provision for protecting the quality of the pancit and also contributing to safeguard the culinary tradition of the community. Most of the communities are 
Table 7 The table below shows the representation of the summarized raw ingredients of Luzon Island pancit dishes. The raw ingredients were divided into fourteen categories. Each category highlights the highest numbered ingredients based from the fieldwork. It also highlights the significant raw ingredients that were used. In general, it only shows that pancit in Luzon Island is diverse (conceptualized by the authors)

\begin{tabular}{|c|c|}
\hline Category & Ingredients \\
\hline Noodles & $\begin{array}{l}\text { Miki* (including Bato, Cabagan, Batac), Bihon, Egg Noodle (including Canton), Misua, Rice Noodle (including } \\
\text { Malabon, Vietnamese, Hofan), Glass Noodle (Sotanghon), Lusay, Naga, Squid Ink Pasta, Spaghetti }\end{array}$ \\
\hline Fresh noodle ingredients & $\begin{array}{l}\text { First Class Flour*, Lye Water (Lihia), Rock Salt, Chicken Egg, Glutinous Rice Flour, Moringa Leaf (Malunggay), } \\
\text { Atsuete Seed }\end{array}$ \\
\hline Fresh and preserved seafood & $\begin{array}{l}\text { Shrimp*, Squid (including the Ink), Mini Clams (Ala), Crab (Alimango / Alimasag), Oyster, Fish (e.g.: Galunggong) } \\
\text { Shrimp Cracker* (Kropek), Fermented Fish Paste, Fermented Shrimp Paste, Canned Sardines, Smoked Fish (Tinapa), } \\
\text { Fish Ball, Squid Ball, Dried Squid }\end{array}$ \\
\hline Fresh and processed meat & $\begin{array}{l}\text { Pork Meat* (Pigue, Kasim, Liempo), Pork Entrail (Liver, Intestine), Pork Bone, Pork Blood, Pork Fat, Pork Knuckle (Pata), } \\
\text { Pork Head, Pork Chicharon } \\
\text { Beef Meat*, Beef Shank, Beef Entrail (Tripe, Liver), Beef Head } \\
\text { Carabao Meat* (Kara Beef) } \\
\text { Kikiam*, Spanish Chorizo, Meat Ball, Filipino Sausage (Longganisa_Laoag and Lucban), Canned Braised Pork Knuckle, } \\
\text { Pork Dumpling }\end{array}$ \\
\hline Poultry and game & Chicken Meat*, Chicken Gizzard, Duck Meat \\
\hline Herbs, spices, and seeds & $\begin{array}{l}\text { Garlic*, White and Red Onion, Ginger } \\
\text { Spring Onion*, Leeks, Celery, Chinese Chives (Kutchay), Parsely (Kinchay), Sweet Basil, Coriander Leaf, Sibut or Tong } \\
\text { Kui, Mint Leaf } \\
\text { Ground Black Pepper*, Cayenne Pepper, Atsuete Seed }\end{array}$ \\
\hline Savory and sweet flavorings & $\begin{array}{l}\text { Soy Sauce*, Rock Salt, Fish Sauce, Oyster Sauce, Vinegar (including Bugnay), White Sugar, Fermented Soybean Paste, } \\
\text { Satay Sauce, Special Sauce, Aminos }\end{array}$ \\
\hline Oil and fat & Cooking Oil*, Sesame Oil, Coconut Oil \\
\hline Dairy produce & Chicken Egg*, Duck Egg, Quail Egg, Evaporated Milk \\
\hline Fruit, vegetable, and fungi & $\begin{array}{l}\text { Philippine Lime* (Calamansi), Cucumber Tree (Kamias), Tomato, Green Papaya, Coconut Meat, Coconut Milk } \\
\text { Cabbage*, Carrot, Green Bean (Baguio Bean), Bird's Eye Chili, Chayote (Sayote), Snow Cabbage (Baguio Pechay), } \\
\text { Pincer (Patola), Pechay (Bokhoy), Banana Blossom (Puso ng Saging), Bean Sprout, Garden Pea, Eggplant, String Bean, } \\
\text { Sweet Potato (Camote), Bell Pepper, Mustard Leaf, Baby Bamboo Shoot, Bottle Gourd (Upo), Finger Chili, Squash, } \\
\text { Okra, Winged Bean } \\
\text { Oyster Mushroom*, Cloud Ear Mushroom (Tengang Daga), Shitake Mushroom }\end{array}$ \\
\hline Grains and by-product & Rice*, Peanut, Tofu \\
\hline Thickening agent & All Purpose Flour*, Glutinous Rice Flour, Potato Starch, Cassava Starch \\
\hline $\begin{array}{l}\text { Food preservatives and } \\
\text { additives }\end{array}$ & Monosodium glutamate* (Vetsin), Liquid Seasoning, Bouillon Cube \\
\hline Others & Dumpling Wrapper, Ketchup \\
\hline
\end{tabular}

* Based on the pancit culinary heritage mapping in Luzon Island, these are considered as the most frequently used ingredients per category

patronizing their hometown public markets. People are known for buying their raw ingredients from this kind of markets because it is cheaper compared with structured markets like supermarkets and the provision of offering fresh and quality ingredients. This kind of culture was developed due to the influence of historical trading and commerce that are being commenced by different foreign trading partners and colonizers like China, Mexico, and Spain [43]. Major trading posts are located to the public thoroughfares just like today's public markets, which are typically located with the town proper or coastline areas.

Aside from the availability of raw ingredients and materials from the public market, people are also concerned in getting their products from a specific supplier, which is known for their quality standards of production and commercialization. This was also mentioned during the in-depth interviews, which concentrated on the context of having or being a "Suki" or a loyal or frequent customer for a certain establishment.

Other sources of raw ingredients are coming from different locally based producers and agriculture-based resources such as Slow Food and Farm-to-Table system. It is from this context that the significance of locally produced ingredients and the sustainability of the Culinary Heritage through the effort of the community specifically on propagation and production is emphasized.

\section{Cooking materials and equipment}

For the pancit culinary heritage, it is important to determine how the dish is being prepared and what are the associated materials and equipment used. Basically, the most important component of the dish is the noodle itself. Most of the communities are making their own 
noodles but it differs based on the materials and equipment used. For some such as in Panciteria de Lipa in Lipa City, Batangas; and Cesar and Chato's Miki Niladdit in Aparri, Cagayan, they used traditional tools such as Kabayo or Jako, which is a long wooden tool for kneading the noodle dough. Some are using liquor bottle to knead and flatten the noodle dough. However, because of commercialization and an increase in the demand, some noodle makers and panciterias decided to use both the traditional and modern equipment. For instance, Haite's Miki Factory in Laoag City, Ilocos Norte, uses both the Kabayo and noodle presser to knead and cut fresh noodles.

The usage of traditional cooking equipment is also being practiced by some of the panciterias and communities. A typical example of this traditional equipment is the usage of pugon and kalang kahoy, which are both used to cook food by means of using wood or rice husk (ipa). Some of the notable panciterias that still use this kind of technology are Nory's Restaurant in Bocaue, Bulacan; Cantina de Tita A in Cavite City, Cavite; and Nang Lazon Log Log Kinalas Sinapot and Toron in Nabua, Camarines Sur. Generally, most of the communities are using gas ranges to cook pancit because of its effect of comfortability and convenience especially to those who operate the panciterias.

In the process of cooking, the communities are using typical materials and tools that were influenced by foreign entities such as the Chinese. In cooking, people are typically using wok, stock pot, soup ladle, and sautéing ladle. This variation of tools is based on what kind of noodle dish is being cooked. If the process is more on stir-frying or sautéing, people would use wok; but if the noodle dish is soupy either thick or thin, people make use of stock pot and even casserole. For a special kind of noodle dish, people also use the strainer (pancit palabok dishes, for example), grater, squeezer, and mortar and pestle for preparation and cooking.

For some, the cooking materials and equipment are also considered as part of their family heritage, which was passed down from generation to generation. They also believed that these materials can enhance the flavor and palatability of the noodle dish. And for some, they consider it as "pampaswerte" or a material that provides good luck and fortune especially for panciteria or noodle-based businesses. Table 8 provides the summary of cooking materials and equipment typically used in Luzon Island for pancit dishes.

\section{Process of cooking}

The process of cooking practiced for Luzon Island's pancit dishes typically starts by sautéing the ingredients in hot fat or oil. Then from that, the other process of cooking is based on what kind of pancit dishes would have to be prepared. If it is in a soup-based noodle dish, simmering and boiling are the typical processes done. Then if there are ingredients, especially for the noodles and the vegetables that are needed to be cooked quickly in hot water or broth, blanching is performed. For some, like Pancit Lusay in Laoag City, Ilocos Norte, tossing is the main process of cooking, which is just like preparing a fresh vegetable or fruit salad. There are also toppings such as kikiam, chicharron, and glutinous rice okoy added to complete the noodle dish. At that point, panfrying and deep-frying are executed. For Pancit Batil Patong of Tuguegarao City, Cagayan, poaching the egg as topping is considered as a traditional component of the noodle dish.

As fresh noodles are an important factor for a pancit dish, the process of making it is also an important identity to be determined. Kneading is an important method of preparation. Other typical process or methods of cooking used in Luzon Island for pancit dishes are pureeing (for the sauces), steaming (for dimsum toppings, for example), and braising (for thick soup meat-based dishes).

Generally, pancit dishes in Luzon island has the following components to complete the dish: the stock, which features the meat or seafood flavor; fresh or commercialized noodles that are being produced by either local producers or manufacturing companies; the sauce especially for noodle dishes that requires it such as Pancit Luglug and Pancit Palabok from Metro Manila and Central Luzon Region, respectively; and the toppings

Table 8 The table below shows the representation of the summarized Luzon Island pancit cooking materials and equipment. The materials and equipment were group into five categories. The groupings were based from the fieldwork done for the research. This only shows that the diversity of pancit as a culinary heritage entity of the Island is significant. This is also based from the community's cultural identity (conceptualized by the authors)

\begin{tabular}{ll}
\hline Category & Cooking materials and equipment \\
\hline Noodle making tools and equipment & Kabayo, Jako, noodle presser, noodle kneading machine, liquor bottle, mixer, noodle cutter, knife \\
Cooking equipment & Gas range, Pugon, Kalang Kahoy, wood (Gatong), rice husk (Ipa), Aromang Kahoy, flat iron \\
Pots, pans, and containers & Wok, stock pot, casserole, sautéing pan, frying pan, bowl \\
Measuring devices & Soup ladle, sautéing ladle, noodle ladle, tongs \\
Knives, hand tools, and small equipment & Strainer, grater, squeezer, mortar and pestle \\
\hline
\end{tabular}


that provides added texture, flavor, and aesthetics for the noodle dish.

\section{Consumption}

Table 9 shows the process and details about the consumption of Luzon Island Pancit dishes. Different food utensils such as spoon, fork, bowl, and plate are the typical tools used by the community especially for individual consumption. For large amount or quantity cooking and preparation, the community uses bilao or a circular type of food container which is made from dried bamboo wood.

For take-out noodle dishes from the panciteria or noodle-based business establishment, the traditional way of using banana leaves and paper is still being practiced. Using the said materials, they produce a balisungsongshaped or a cylindrical-shaped container. Pancit Puso from Cavite City, Cavite; Pancit ni Mang Biko from Taal, Batangas; and Pancit Canton from Boac, Marinduque, are some of the pancit dishes that do make use of the cylindrical-shaped container.

To contrast and even to enhance the original flavor and palatability of the pancit dish, people in Luzon Island created different kinds of sauces. Out of all the sauces, the traditional Philippine lime or calamansi juice is the typical ingredient to provide the sour flavor, contrary to the savory and salty flavor of the dish.

Filipinos are known for food pairing. This was highlighted by different researches and articles about food that was created by different culinary historians of the Philippines [44]. For pancit dishes in Luzon, there are different food pairings that are developed by the community based on their historical and cultural context. Because of its savory and salty taste, people consider it as a viand. It is usually paired with steamed rice especially during breakfast, lunch and dinner. If the pancit dish is being eaten for a morning or afternoon snack, people would pair it with bread specifically hot pan de sal, lumpiang ubod or sariwa, steamed puto (either flour or rice-based), and even different kinds of banana-based dishes.

\section{Recycling and disposal of waste}

In terms of sustaining the natural environment, determining the significance of providing efforts on how food establishments create sustainable programs especially on recycling and disposal of waste is also important. For most of the panciterias and restaurants offering pancit dishes in Luzon Island, many of them would dispose of their vegetable trimmings and leftovers as food for domesticated (e.g., pets) and farm-raised animals (e.g., hogs and poultry chicken). The community also adheres to the respective policies and ordinances of their province, municipality and city on waste segregation and collection. For some, they make compose pits and implement vermiculture to promote sustainability especially for garbage and waste management. Thus, the establishments are also helping their local farmers especially on sustainable agricultural development.

There are also alternative ways to limit the usage of plastics and other related materials, one of which is by using reusable containers in compliance with the plasticfree ordinances ratified by their local government units.

\section{Namnamin: discussion of culinary heritage significance of Philippine noodles in Luzon Historical significance}

Pancit in the Philippines is an acculturated dish coming from different foreign entities and culture [41, 42]. This started when the early Chinese traders and migrants

Table 9 The table below shows the representation of the summarized Luzon Island pancit process of consumption. The details below were divided into four factors. These factors represent the way on how pancit is being consumed by the Filipinos in Luzon Island. These are all based from the culinary heritage traditions of the community. The table also highlights the significant materials and equipment that are normally used (conceptualized by the authors)

\begin{tabular}{|c|c|}
\hline Factors & Details \\
\hline Food utensils & $\begin{array}{l}\text { Spoon*, fork*, chopstick, banana cue stick } \\
\text { Bowl*, plate*, Bilao, paper cup, sizzling plate, mini wok, coconut shell, bamboo base, clay pot } \\
\text { Shell cracker }\end{array}$ \\
\hline Take-out utensils and materials & Banana leaves*, paper*, plastic, microwavable container, styro \\
\hline Sauce & $\begin{array}{l}\text { Philippine lime (Calamansi)*, chili oil, white and red onion; vinegar, bird's eye chili, soy sauce, } \\
\text { Kilawing Puso ng Saging, ground black pepper, sweet sauce, Aminos }\end{array}$ \\
\hline Food pairing & $\begin{array}{l}\text { Steamed rice* } \\
\text { Bread (preferably Pan de Sal)*, Kinamachele, Jacobina, Binanle, Sortido } \\
\text { Lumpiang Ubod or Sariwa*, Halo-Halo, Siopao, Lumpiang Shanghai, Empanada (including Batac), } \\
\text { taco, Siomai, ice cream, pork barbeque, fried Galunggong, fried Dilis } \\
\text { Puto*, Patupat, Biko, Pinakufu, Bibingkoy, Minukmok or Nilupak, Putong Pula, Bibingkang Malagkit, } \\
\text { cassava cake } \\
\text { Sinapot or Maduya, Turon, boiled banana, banana cue } \\
\text { Coffee, chocolate drink }\end{array}$ \\
\hline
\end{tabular}


visited the Philippines [12] to promote their products and services. Most of them established their own communities, which are located to major trading posts and centers of the Philippines especially during the Pre-colonial period in Luzon [45]. Some of these are the Vigan City, Ilocos Sur [46]; the Province of Cagayan [47]; and the City of Manila [12]. In this context, two identical groups of Chinese from Mainland China migrated and traded in the Philippines: the Fujianese from Fujian Province [1] and the Cantonese from the Guangdong province (formerly Canton) [20, 48]. Rapidly, the Chinese also transferred from one area to another within the Philippines to venture for new opportunities. Some of them build their own businesses; others offered their own services as cooks and waiters; hence, the culinary tradition of cooking and consumption of pancit were transferred to the local community.

One of the products and culture that was introduced by the Chinese to the Filipinos is the consumption and the process of noodle making. One of evidences is a testimony appearing in the docketed papers on a consequence of a Royal Resolution in the re-admission of the Chinese to the Philippine islands dated 25-29 October 1779 [20] wherein noodle and pancit makers and cooks are included in the trip going to the Philippines. Because of this, the Filipinos acculturated the tradition and developed it as one of the iconic culinary identities of the Philippines. Today, there are different kinds and varieties of pancit dishes in the country specifically in Luzon. For some, it is already considered as a trademark not just in an area but in the region (e.g., Pancit Batil Patong and Cabagan for Region 2; and Pancit Bato for Region 5). Based on the concept of establishing different panciterias in the Philippines especially in Luzon, most of it were built and developed in the early to mid-1900s to different places and areas. The Chinese community and their respective businesses and establishments were strengthened in this period because during that time, in the American colonization period, the Americans prioritized and provided different opportunities to all races either mestizos, sangleys (Chinese migrated in the Philippines) or indios in the Philippines [49]. From this measure, different communities prospered and provided free entity on business and investment.

Before the concept of a progressive development of panciterias in the Philippines, Chinese and ChineseFilipino noodle makers were first established their own production of indigenized noodles. This was becoming a trademark for most of the areas in Luzon and until today, there are noodle factory houses that are still operating. Some of the notable heritage noodle factories are Asiong and Haite in Ilocos Norte; Vigan Miki Factory in Ilocos Sur, Luzon Mikki Mart in Quezon, Ka Charing and Moderna in Marinduque; and J. Sesgundo Pancit Factory in Camarines Sur. It was through the noodle factories that different panciterias were established. The tradition of purchasing the traditional noodles from different heritage noodle factories and offering a cooked pancit dish from the panciterias would still be practiced. Some of the panciterias which are considered to be the oldest food establishments in the country are New Toho Food Center or Sin Ho Hing Restaurant (1880, City of Manila), Masuki (City of Manila), Ma Mon Luk (Quezon City), Old Center Panciteria (Quezon Province), and Chi Wing's Canton Panciteria (Marinduque).

Aside from the influence of the Chinese community, there were also different accounts on how local pancit dishes started in an area. There are accounts that it is related to the history of the town (e.g., Malabon City, in history, is known for having a number of labong-Pancit Labong to Pancit Malabon development), associated built heritages (e.g., Pancit Estacion was started in a panciteria near the old Rail station in Tanza, Cavite) or from the associated social context such as an event (e.g., Calandracas in Tanza, Cavite, was originated because of the lamay or wake, wherein people would offer different agricultural produce and placed it on the calandra or the vehicle used for transporting the corps from one place to another).

\section{Spiritual significance}

Filipinos are considered to be one of the most religious societies in the world [50]. It was stated from the report under the 2015 Global Attitudes Survey of the United States-based Pew Research Center that "nearly nine out of ten Filipinos or eighty-seven percent (87\%) consider religion very important in their lives" [50]. In culinary heritage, faith and religion are also integrated as it is already part of the lifestyle of the people. For most of the panciterias, as part of their tradition, offering a prayer or thanksgiving to God is a must for guidance before they start their operation. A day is not complete for them if they will not pray at all.

In the Chinese tradition, they believe that they need to offer something to their gods. For food businesses such as panciteria, normally, they need to offer all kinds of pancit dishes available in their menu or their best sellers. For them, this symbolizes progress, good luck, wealth, thanksgiving, and guidance. They also believe that offering pancit dishes to their gods would mean long life and prosperity for their own lives, their family and relatives; and for their business $[1,20,41,42]$. The Chinese also introduced the concept of buena mano or the first product that was sold in a day.

Pancit dishes are also important food to serve especially during important religious activities. They are serving it during Padasal or Prayer for the Dead (e.g., Sinanta from Tuguegarao City, Cagayan), wakes (e.g., Calandracas from Tanza and Cavite City, Cavite), burial 
(e.g., Pancit Musiko from Vigan City, Ilocos Sur), Holy Week (e.g., Laksa from Angono, Rizal), and even for a special festival or festivity (e.g., The Original Mami during the La Naval Festivity in Quezon City). This is being done because pancit is easily cooked, large in quantity since it could serve more people, and even versatile in its flavor (chicken, seafood, and vegetables). There is also a communal lifestyle that after attending important religious gatherings such as hearing Mass every Sunday for Catholics, they would eat in a panciteria (e.g., Lomi from Lipa City, Batangas).

The owners of the panciteria also have their own adjustment on the dietary requirements of different religious groups. They already adjusted especially on the restricted and allowed ingredients and also in the process of cooking (e.g., the Islam religion believes on Halal cuisine - no pork and is restricted on the process of slaughtering and cooking meats from animals). Most of the panciterias provide different varieties of pancit dishes in adherence to religious-oriented policies (e.g., Pancit Bicol Express from Daraga, Albay).

\section{Culinary significance}

The culinary context of heritage is an essential component for understanding the cultural value of local food [51]. It was also highlighted from the research about the sustainable development of culinary resources of a community, which was important in order to determine its culinary identity and values.

In terms of food etymology, the names of pancit dishes in Luzon are based on different factors. Table 10 exhibits the origin of the names of different pancit dishes in Luzon.
Since the Chinese migrant profile are mostly Fujianese and Cantonese, their identical and identifiable process and methods of cooking are also transmitted to the local community. Fujian cuisine is more on braising and boiling, which results to soup-based dishes; while the Cantonese cuisine is more on stir-frying and sautéing, which results to a stir-fried dish [52]. This can also be observed with most of the Luzon Pancit dishes, which was based on their historical and culinary context. For instance, Lomi in Lipa City, Batangas, was introduced by a Chinese from Fujian. Lomi is a braised type of noodle, in which, anything braised is reflected of the Fujian cuisine. In Boac, Marinduque; Pancit Canton from Chi Wing's Canton Panciteria was introduced by a person coming from Canton province. Pancit Canton is a stir-fried noodle dish, in which anything stir-fried is reflective of the Cantonese cuisine. The Chinese also shared the context of using quality and fresh ingredients (e.g., vegetables, meat, and noodles); the concentration of extracting the natural flavor of the animal meat, seafood or fish and the precision on preparation specifically in cutting. These factors are always basic procedure and standards for Chinese cooking [53]. Variations and versatility on the usage of the noodles are also observed in the pancit culinary heritage of the Filipinos in Luzon (e.g., Pancit Canton-Bihon, Pancit Miki-Bihon, Miki-Bihon Soup, Lobihon, Lomisua, Lomi).

But even though pancit is an acculturated dish, it was developed based on the culinary context of the local community. The late highlighted that Filipino Food is an indigenized version of all foreign food that were introduced to us by different culture and tradition [1]. Ilokano Pancit dishes such as Pancit Lusay and Hibol, for

Table 10 The table below shows the representation of the origin of the names of some pancit dishes in Luzon Island. The etymology of the names signifies the importance of cultural communities and its related aspects. The factors identified below highlights the significance of the findings identified from the fieldwork. These information matches different evidences specifically the physical, oral, and archival. Some of the pancit dishes identifies as well as the area of concern are some of the examples identified from the fieldwork (conceptualized by the authors)

\begin{tabular}{|c|c|c|}
\hline Factors & Name of the pancit & Area \\
\hline Name of the noodles & Miki & Batac City, Ilocos Norte \\
\hline Characteristics of the noodle dish & Pancit Lusay (which means overcooked) & Laoag City, llocos Norte \\
\hline \multirow[t]{2}{*}{ Process of cooking } & Miki Nilad-dit (from the word niladit, which means to flatten) & Aparri, Cagayan \\
\hline & Pancit Pinagulong (which means to roll) & Marikina City \\
\hline \multirow[t]{2}{*}{ Process of consumption/eating } & Pancit Sabsab (which means eating it directly using the mouth) & Taal, Batangas \\
\hline & Pancit Habhab (which means eating it directly using the mouth) & Lucban, Quezon \\
\hline \multirow[t]{2}{*}{ Important personality } & Pancit Henoy (named after Gen. Emilio Aguinaldo) & Kawit and Cavite City, Cavite \\
\hline & Pancit Maciang (nickname of the person who offered/invented the pancit dish) & San Pedro City, Laguna \\
\hline Specific ingredients or component & Almondigas (coming from the word Albondigas, which means meatballs) & Cavite City, Cavite \\
\hline Associated material & $\begin{array}{l}\text { Calandracas (coming from the word Calandra, which is the vehicle used to } \\
\text { transport the corps) }\end{array}$ & Tanza and Cavite City, Cavite \\
\hline Name of the place or area of concern & Pancit San Juan & San Juan City \\
\hline
\end{tabular}


example, mirros on the communities' culinary identity. Hibol or high voltage is made from stir-fried miki noodles with Sinanglaw or their version of boiled beef meat and innards. Pancit Lusay, on the other hand, uses the tradition kamatis (tomato), bagoong (fish paste), and lasuna (onions) or abbreviated as KBL as a major flavoring component.

As for Luzon pancit dishes' taste characteristics, the pancit can be salty (soy sauce, fish sauce, salt, fish paste), umami (Monosodium glutamate), savory (meat flavor), sour (Philippine lime or calamansi, vinegar used for kilawin), sweet (sugar, satae sauce, aminos sauce), and spicy (bird's eye chili, finger chilis, ground black pepper). These taste characteristics are the same with Chinese cuisine [52].

The culinary tradition of cooking and eating pancit is continuously evolving through the influence of modernization and technology. Nowadays, the commercial and business entities developed different kinds of instant pancit dishes that can be cooked for just 5 min (e.g., Lucky Me! Instant Pancit Canton). If they wanted to infuse complex flavor and component to the dish, they developed canned or processed meats such as canned braised pata or pork knuckles. To enhance the flavor and taste of the dish, people use different food preservatives and additives such as monosodium glutamate, bouillon cubes, and liquid and powdered seasonings. Precautions and safeguarding measures must be implemented to observe sustainability especially on the values and significances of the culinary heritage $[41,42,54]$.

\section{Social significance}

The perspectives of the community on culinary heritage are important so as to highlight the connection and significance of it to the area concern. The social significance and the identity of the culinary heritage are aspects that are important to motivate people either locals or visitors to nourish and safeguard it [18, 55]. And from this context, it is already considered as the area's culinary heritage value. Some examples are Pancit Batil Patong and Cabagan from Cagayan Valley Region; Pancit Habhab from Quezon Province and Pancit Bato from Bicol Region. Likewise, it is also observed that most of the panciterias or an individual who are offering pancit dishes are located in major public areas such as public markets [20]. It postulated that culinary identities of the community are mostly developed by the community, which is mostly located in public areas like streets, major port areas, commercial centers, and the like.

For the Filipinos in Luzon, pancit is an everyday food. For some, they consider it as a breakfast or snack meal. Others, on the other hand, recognize it as a viand, served during lunch and dinner. Pancit is also a comfort food; a group of Filipinos especially Overseas Filipino Workers
(OFWs) are enticed in cooking, buying, and eating it. It is also a staple food for important gatherings or events such as birthdays even wakes.

Culinary heritage also promotes equality on social aspects especially on status and prestige [18, 55]. Pancit also contributes to this. People of all walks of life-rich, middle or poor, patronize eating of pancit as part of their everyday meal or during special occasions. In Taal, Batangas, the local community and even people from nearby areas, would patronize Pancit ni Mang Biko or Pancit Sabsab. Tricycle drivers, public market workers, construction workers, teachers, government officials and staff, and even managers and owners of different businesses in the area would often be the customers. Aside from that, the community also developed a social tradition in the context of developing the culinary heritage. In Taal, Batangas, the community makes a hissing sound or sitsit which meant they wanted to call someone to take an order or to prioritize then for ordering. The community also signifies the importance of transmitting the tradition from generation to generation. It is also important because it will continuously safeguard the trademark and identity of an individual, the family, and even the societal entity who contributed in the development of the culinary heritage [41, 42].

Aside from the communal context of food especially for pancit, some personalities in Philippine History and Culture and even events and festivities are associated with them. Pancit Henoy from Kawit and Cavite City serves as an example with Cavite being associated with General Emilio Aguinaldo, the First President of the Republic of the Philippines. The Original Mami from Quezon City was influenced by Ma Mon Luk, a Chinese philanthropist who helped by means of financing the Katipuneros or the Philippine Revolutionary soldiers. For events, to sustainably promote the cultural context of the dish, the Local Government Units (LGUs), together with other stakeholders initiated and organized different festivities such as the Lomi Festival in Lipa City, Batangas, Pasayahan sa Lucena in Lucena City, Quezon, and Pancit Kanin Festival in San Jose City, Nueva Ecija to name a few.

\section{Aesthetic significance}

The aesthetic appeal of the documented varieties of pancit from the entire regions of Luzon varies from their own cultural and geographical contexts that made them uniquely different. From the mountain sides and plains, down to coastal areas, the people associated their pancit dishes from the things abundant to the place and those known to its neighborhood. The use of squid ink for instance of the Caviteños from Tanza, Cavite City and Trece Martirez, all of which are located along coastal areas, crafted an artistic imprint and revealed their culinary brilliance by tinting black their Pancit Choko en su 
Tinta and Pancit Estacion Negra which paved the way to its artistic and unique appearance in contrast with the classic variety.

Food historian and author Ige Ramos described in his cookbook that Pancit Choco en su Tinta or Pancit Pusit is an archetypal Chabacano dish, Choko being the Chabacano for cuttlefish, also known as Pancit Pusit or Pancit Negra, because of its black color, was only eaten during Lent or funerals [38]. Topping these two dishes with the contrasting green color of Kamias and the orange color of the fried garlic made it even more attractive even tempting to the eyes.

\section{Economic significance}

It is a recognized fact that originally, the introduction of pancit to the Philippine soil is not for the exclusive purpose of sale and to earn money. In the study of Mercado and Zerrudo [41, 42], they argued that a Fujian native To Kim Eng, the first maker of Lomi in Lipa City, Batangas, introduced this thick savory noodle dish to feed his opponents while and/or after playing Mahjong. Eventually, Lomi became popular in the province of Batangas and influenced its spread all over the country which created regional versions. Similarly, the stories of the Pancit Habhab from Lucban in Quezon Province, Pancit Cabagan from Cabagan, Isabela, and Pancit Batil Patong from Tuguegarao City, Cagayan, caught the attention of tourists from all parts of the archipelago. These local pancit favorites have undeniably created business opportunities for the people from the suppliers of raw ingredients down to the restaurant owners. This economic activity directly influences their province's tourist arrivals, thus, creating a multiplier effect to all sectors.

Pancit significantly influenced almost virtually every eatery and fancy restaurants in Luzon Islands. In every food establishment in the country, pancit is served in one way or another, from soup-based to stir-fried dishes. Take Pancit Ulam from San Jose City, Nueva Ecija, for instance. This dish is virtually a complete meal with the combination of a Novo Ecijano staple, a plate of rice, topped with sautéed Pancit Bihon and ulam, which targets the farmer customers and even regular workers looking for an inexpensive feast for breakfast, lunch, snack, and dinner.

This kind of Filipino affinity for pancit made tangible opportunities for entrepreneurs and restaurant owners. An interview from the owner of an eatery in San Jose, Nueva Ecija, even asserted that this enterprise allowed her to finance her children in a university and eventually supported them to finish their schooling.

\section{Agricultural significance}

The multiplier effect due to Filipinos' attachment with pancit dishes greatly affects the economy as affirmed in the previous discussion. Agricultural sector is not an exemption to the penetration of Filipino pancit cravings; thus, it created ways and methods to organically craft a dish that is not only indigenous to the place but also healthy from the selection of raw ingredients down to its preparation. Such is the case of Pancit Kalabuko from San Pablo City, Laguna, a colorful and unique pancit dish made with squash, mushrooms, and coconut meat as their noodles. The owners shared to the researchers that their restaurant subscribes to organic farming and offers harvests that are offered to the general public. These harvests are locally and naturally grown and served fresh from their Agri-tourism farm and made further sustainable because of their "Integrated Diversified Organic Farming System" (IDOFS) which promotes efficiency as each plant and/or animal serves a purpose outside itself [56]. This concept of innovation through farm-to-table and slow food system supported many people in the agricultural sector and ultimately promoted and showcased the creativity of the Filipinos on making an absolutely healthy culinary art specialty for all ages which as of this writing have drawn international attention due to its uniqueness from all the noodle dishes in the Philippines and the world.

Many agricultural enterprises in the Philippines were developed because of pancit's absolute diffusion to the market. From livestock businesses of Carabao meat of Tuguegarao in Cagayan; Tinapa or dried fish goods of Malabon City in the National Capital Region; shrimp harvesting of Rizal Province to Malabon City's usage of bamboo shoots or "Labong"; Upo or bottle gourd of Batangas Province; the usage of Patola, fermented shrimp paste, Kamias, and Suahe production of Cavite Province made their respective cities and provinces a farming attraction if not an agricultural epicenter.

\section{Symbolical significance}

The Philippine culture and traditions are rich in terms of passing from generations to generations their custom beliefs and traditions most especially superstitious beliefs [57]. It has roots which are acquired from different cultures as well that have conquered us. Filipinos are known to be religious and place so much symbolism almost to everything.

Pancit certainly is not excluded to this widespread belief system. They are frequently served at different celebrations especially during birthdays and Chinese restaurants in the Philippines even have "birthday noodles" listed on their menus. Both the Chinese and Filipinos believe that noodles represent long life and good health; therefore, they must not be cut, as that would "corrupt the symbolism" [58].

Majority of the provinces of Luzon firmly believes that pancit also represents strong family ties and long life 


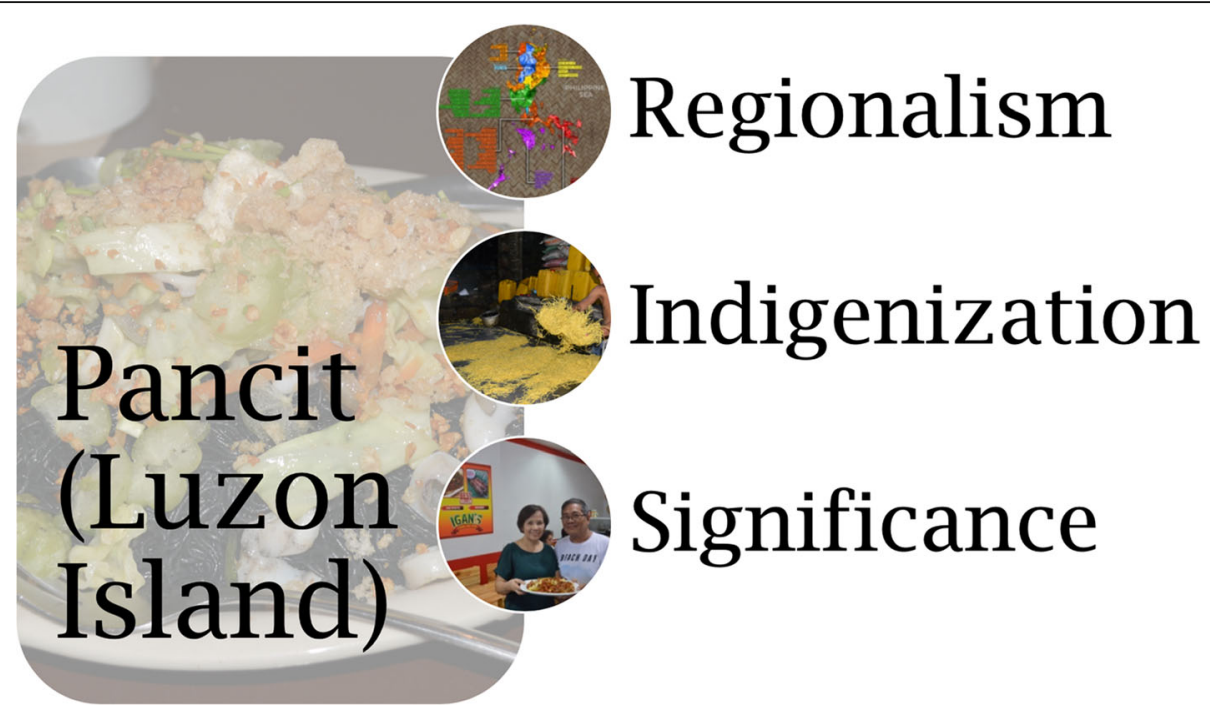

Fig. 5 The figure above shows the Luzon Island Pancit Culinary Heritage Conceptual Framework. The framework is based from the fieldwork and the details identified. The framework has three major components: regionalism, indigenization, and significance. It represents most of the practices of the eight regions in the island. It shows the relationship of pancit to the community and its associated areas (photo from the authors)

[58]. This belief was also mentioned during the interviews conducted by the researchers. In terms of its economic significance, each family business owners look at pancit as the driving force for family togetherness, resiliency, hard work, and dedication. Thus, these businesses consider the introduction of pancit certainly a blessing for the family. Stories from Binondo in Manila Chinatown and virtually every province outside the National Capital Region believe that indeed pancit is a representation of good times omnipresent in family celebrations up to municipal or provincial festivities.

\section{Conclusion}

Aside from nourishing the need of the body to eat and sustain its health through the provision of attaining vitamins and minerals, food is an identity of the community. It helps people to understand and appreciate their own local culture and tradition by means of eating and using the sense of taste. Even though the culinary tradition is indigenous or acculturated from other tradition, this reflects to the rich cultural diversity of the community.

Pancit, in the context of acculturation and the local community, highlights how the Filipinos adjusted and developed it as an ordinary tradition. From this context and based on the findings of the research, there are three important factors in the culinary heritage of pancit tradition specifically in Luzon Island and these are regionalism, indigenization, and significance.

Pancit tradition was developed in different parts of the country specifically in Luzon because of migration and commerce influenced by the Chinese to the Philippine
Islands. As the tradition was introduced in different parts of Luzon Island, pancit was also developed based on the culture and heritage of the community as well as the indigenous agricultural and geographical resources available. In general, pancit was already a representation of a regionalist identity since it was developed through time and made it as an identity of an area and its community. Because of this context, pancit is already an indigenized food of the community, which highlights the raw ingredients and its related environment; the traditional materials and tools for preparation and cooking; process of cooking, consumption, and the disposal and recycling of waste. From this aspect of indigenization, it resulted to the change of pancit's culinary identity from a Chinese-influenced culture to a locally developed tradition. Since it was totally accepted by the local community, different significances and values that are related to historical, spiritual, culinary, social, aesthetic, economic, agricultural, and symbolical aspects were developed. These provided a complex story of pancit to the community, which highlights its indigenized contribution and at present, its sense of regionalism (Fig. 5).

Pancit is an example of a culinary heritage of the Filipinos that was developed through time. This development contributes to the development of the community's identity and values. Even though it was an acculturated dish from the Chinese, Filipinos developed it and provided their own identity that makes it indigenized and strengthened their regionalist identity. This shows that pancit became one of the local culinary heritages of the Filipinos. As what the late Doreen Gamboa-Fernandez said, "Food, obviously, is not only for eating." [44]. 


\section{Acknowledgements}

This research acknowledges the approval and support of the following institutions and individuals: the National Commission for Culture and the Arts (NCCA) under the NCCA Research Grant Program 2019, the University of Santo Tomas Graduate School-Center for Conservation of Cultural Properties and the Environment in the Tropics (USTGS-CCCPET) headed by Assoc. Prof. Eric B. Zerrudo, PhD, UST College of Tourism and Hospitality Management (CTHM) headed by Assoc. Prof. Atty. Gezzez Giezi G. Granado, DCL, CHE and Asst. Prof. Maria Cecilia A. Tio Cuison, MEd, CHE, CGSP (the former Dean); UST Research Center for Social Sciences and Education headed by Prof. Belinda V. De Castro, PhD, Asst. Prof. Maria Regina Policarpio-Arriero, MA from the UST Department of English, Mr. Gil Ernest M. Gatinga and Mr. Al Reile S. Dela Torre.

\section{Authors' contributions}

The abovementioned authors conceptualized, implemented, and wrote the research proposal, fieldwork and the paper respectively. The authors read and approved the final manuscript.

\section{Authors' information}

Jame Monren T. Mercado, MACHS is a Faculty Member and the Research Coordination from the Tourism Management Department of the University of Santo Tomas (UST)-College of Tourism and Hospitality Management (CTHM) and a Faculty Research Associate (Tier 2) under the UST-Research Center for Social Sciences and Education (RCSSEd).

Avi Ben P. Andalecio, MA, is a Faculty Member and the Community Development Coordinator of the College of Tourism and Hospitality Management (CTHM) of the University of Santo Tomas (UST) in Manila. In the same university, he is also a Faculty Research Associate (Tier 1) under the Research Center for Social Sciences and Education (RCSSEd).

\section{Funding}

This research is officially acknowledging financial support of the National Commission for Culture and the Arts (NCCA) under the NCCA Research Grant Program 2019 and the Research Center for Social Sciences and Education (RCSSEd) of the University of Santo Tomas (UST), Manila, Philippines. These institutions covered for the research fieldwork and documentation expense.

\section{Availability of data and materials}

The datasets generated and/or analyzed during the current study are not publicly available due the restrictions mandated by the funding institution, the National Commission for Culture and the Arts (NCCA) but are available from the corresponding author on reasonable request.

\section{Competing interests}

The authors declare that they have no competing interests.

\section{Author details}

${ }^{1}$ College of Tourism and Hospitality Management, University of Santo Tomas, España Boulevard, 1008 Manila, Philippines. ${ }^{2}$ Research Center for Social Sciences and Education, University of Santo Tomas, España Boulevard, 1008 Manila, Philippines. ${ }^{3}$ Center for Conservation of Cultural Property and the Environment in the Tropics, University of Santo Tomas, España Boulevard, 1008 Manila, Philippines. ${ }^{4}$ The Graduate School, University of Santo Tomas, España Boulevard, 1008 Manila, Philippines.

Received: 3 December 2019 Accepted: 14 May 2020

Published online: 29 May 2020

\section{References}

1. Fernandez D. Palayok: Philippine food through time, On Site, In the Pot. Makati City: Bookmark; 2000.

2. UNESCO. The Convention for the Protection of the World Cultural and Natural Heritage. United Nations Educational, Scientific and Cultural Organization. 1972. http://whc.unesco.org/en/conventiontext/. Accessed 23 Nov 2019.

3. UNESCO. (2003). The convention for the safeguarding of the intangible cultural heritage. United Nations Educational, Scientific and Cultural Organization. 2003. https://ich.unesco.org/doc/src/15164-EN.pdf. Accessed 23 Nov 2019.
4. Lee S. Malaysia: the impact of modernization on ethnic food. Chiang Mai: Chiang Mai University; 2015.

5. Badilla M. Tourism Marketing. Manila: Rex Bookstore; 2015.

6. Alfino M, Caputo J, Wynyard R. McDonalization revisited: critical essays on consumer culture. Westport: Praeger; 1998.

7. Du rand $\mathrm{G}$, Heath $\mathrm{E}$, Alberts N. The role of local and regional food in destination marketing: a South African situation analysis. J Travel Tour Mark. 2003;14(3-4):97-112.

8. Telfer D, Wall G. Linkages between tourism and food production. Ann Tour Res. 1996:23(3):635-53.

9. Besa A. The birth of Ang Sariling Atin culinary heritage institute food that was ours. New York: Purple Yam; 2010. http://www.purpleyamnyc.com/thebirth-of-ang-sariling-atin-culinary-heritage-institute-that-was-always-ours. Accessed 23 Nov 2019.

10. Panlilio E, Sta. Maria F. Slow Food: Philippine Culinary Traditions. Pasig City: Anvil Publishing; 2006

11. Blair E, Robertson A. The Philippine Islands 1493-1803. Arthur H. Clark Co: Ohio; 1903.

12. Chu R. Chinese and Chinese Mestizos of Manila family, identity and culture 1860s-1930s. Manila: UST Publishing House; 2010.

13. Fox R. The archaeological record of chinese influences in the Philippines. Philipp Stud. 1967;15(1):41-62.

14. Go J. Ma'l in Chinese records - Mindoro or Bai? An examination of a historical puzzle. Philipp Stud. 2005;53(1):119-38.

15. Wang Z. Reading Song-Ming records on the pre-colonial history of the Philippines. Journal of East Asian Cultural Interaction Studies. 2008;1: 249-60.

16. Wernstedt F, Spencer J. The Philippine island world: a physical, cultural and regional geography. California: University of California Press; 1967.

17. Scott W. Barangay: Sixteenth-century Philippine Culture and Society. Quezon City: Ateneo de Manila University Press; 1994.

18. Neuman N. On the engagement with social theory in food studies: cultural symbols and social practices. Food, Culture \& Society. 2018;22(1):78-94.

19. Bahay Tsinoy. Early Contacts. Bahay Tsinoy: Museum of Chinese in Philippine Life, Manila. 2019. http://www.bahaytsinoy.org/early-contacts/. Accessed 23 Nov 2019.

20. Sta. Maria F. The Governor-General's Kitchen: Philippine Culinary Vignettes and Period Recipes 1521-1935. Pasig City: Anvil Publishing; 2006.

21. El RJ. Filibusterismo (1891). Hawaii: University Hawaii Press; 2007.

22. Tayag C, Quioc M. Linamnam: eating one's way around the Philippines. Mandaluyong City: Anvil Publishing; 2012.

23. Department of Trade and Industry. Bantay Presyo. Department of Trade and Industry, Quezon City. 2014. https://drive.google.com/folderview?id=0B9g4 Z7P_-NePRV84NGITWDFKMmc\&usp=sharing. Accessed 23 Nov 2019.

24. Shin H, Cho E, Lee H, Fung T, Rimm E, Rosner B, Manson J, Wheelan K, Hu F. Instant Noodle Intake and Dietary Patterns Are Associated with Distinct Cardiometabolic Risk Factors in Korea. J Nutr. 2014;144(8):1247-55.

25. Scott, W. Filipinos in China Before 1500. University of the Philippines. 1983. https://www.asj.upd.edu.ph/mediabox/archive/ASJ-21-1983/scott.pdf. Accessed 23 Nov 2019.

26. Pike, J. The China Trade - Philippines History - Porcelain Period. GlobalSecurity.org. 2014. https://www.globalsecurity.org/military/world/ philippines/history-early-china.htm. Accessed 23 Nov 2019.

27. Wu J. Reaction of the Philippine society to the "Belt and Road" initiative. Southeast Asian Affairs. 2016:4:31-42.

28. Ray, M. Luzon. Encyclopedia Britannica. 2019. https://www.britannica.com/ place/Luzon. Accessed 23 Nov 2019.

29. Columbia University Press. The Columbia Electronic Encyclopedia. $6^{\text {th }}$ ed. United States: Columbia University Press; 2012.

30. Australia ICOMOS. The Burra Charter: The Australia ICOMOS Charter for Places of Cultural Significance. Australia ICOMOS. 2013. https://australia. icomos.org/wp-content/uploads/The-Burra-Charter-2013-Adopted-31.10.2 013.pdf. Accessed 20 Nov 2019

31. Congress of the Philippines. Republic Act No. 10066: The National Cultural Heritage Act of 2009. Congress of the Philippines. 2009. https://www. officialgazette.gov.ph/2010/03/26/republic-act-no-10066/. Accessed 23 Nov 2019.

32. Sta. Maria F. What Kids Should Know About Filipino Food. Quezon City: Adarna House; 2016.

33. NCCA. Cultural Mapping Program. National Commission for Culture and the Arts. 2019. https://ncca.gov.ph/about-ncca-3/ncca-cultural-mappingprogram/. Accessed 23 Nov 2019. 
34. Zerrudo E. Pamanaraan: Writings on Philippine Cultural Heritage Management. Manila: UST Publishing House; 2008.

35. Boyce C, Neale P. Conducting in-depth interviews: a guide for designing and conducting in-depth interviews for evaluation input. Pathfinder International: Massachusetts; 2006.

36. Gueguen C. New Migrants from Continental China in Philippine Cities: Differences in Profiles and Settlements. Rev Eur Migr Int. 2012;18(4):127-43.

37. O'Brien JJ. The historical and cultural heritage of the Bikol people. Naga City: Ateneo de Naga University; 1993.

38. Ramos G. Republic of Taste: The Untold Stories of Cavite Cuisine. Ige Ramos Design Studios: Makati City; 2018.

39. Gliane, N., Delupio, N., Kahiwat, J., Comedis, E. Pancit Malabon: Malabon Heritage. De La Salle University, Manila. 2015. https://www.dlsu.edu.ph/wpcontent/uploads/pdf/conferences/research-congress-proceedings/2015/ LCCS/003LCS Gliane_NGM.pdf. Accessed 23 Nov 2019.

40. Lantrip, B. The Chinese Cultural Influence on Filipino Cuisine. The University of San Francisco, United States of America. 2017. https://repository.usfca. edu/cgi/viewcontent.cgi?article=1334\&context=thes. Accessed 23 Nov 2019.

41. Mercado J, Zerrudo E. Pamanang Kulinarya: developing a safeguarding plan for culinary heritage using the statement of significance approach - the case of Lomi in Lipa City, Batangas, Philippines. SPAFA Journal. 2018;2:1-33.

42. Mercado J, Zerrudo E. Rekado ng Kwento: The culinary heritage significance of Lomi in Lipa City, Batangas, Philippines. Journal of Philippine Tourism and Hospitality Studies. 2019:1:1-16.

43. READ Foundation. The Manila Galleon. Quezon City: READ Foundation; 2014.

44. Fernandez D. Culture ingested: notes on the indigenization of Philippine food. Philipp Stud. 1988;36(2):219-32.

45. Presidential Museum and Library. Pre-colonial Manila. Malacañang Palace Presidential Museum and Library, Manila. 2019. http://malacanang.gov.ph/75 832-pre-colonial-manila/. Accessed 23 Nov 2019.

46. UNESCO Bangkok, the City Government of Vigan. World Heritage City of Vigan, Philippines: Heritage Homeowners Preservation Manual. Bangkok: UNESCO Thailand; 2010

47. Tan A. The Chinese Mestizos and the formation of the Filipino nationality. Archipel. 1986;32:141-62

48. Guldin G. The ebbing of the overseas tide: Fujian, the Philippines and the rice of the PRC. Asian profile. 1980;8(6):505-20.

49. Chu R. The "Chinese" and the "Mestizos" of the Philippines: towards a new interpretation. Philipp Stud. 2002;50(3):327-70.

50. Bagaoisan, A. Why Filipinos are among world's most religious. ABS-CBN News, Quezon City. 2016. https://news.abs-cbn.com/focus/01/07/16/whyfilipinos-are-among-worlds-most-religious. Accessed 23 Nov 2019.

51. UNWTO, Basque Culinary Center. Guidelines for the Development of Gastronomy Tourism. Madrid: United Nations World Tourism Organization; 2019.

52. Ma G. Food, eating behavior, and culture in Chinese society. Journal of Ethnic Foods. 2015;2(4):195-9.

53. Schlotter K, Spielmanns-Rome E. Culinaria China: A Celebration of Food and Tradition. Germany: H.F. Ullmann Publishing Gmbhl; 2015.

54. Poulain, J., Smith, W., Laporte, C., Tibere, L., Ismail, M., Mognard, E., Aloysius, M., Neethiahnanthan, A., Shamsul, A. Studying the consequences of modernization on ethnic food patterns: Development of the Malaysian Food Barometer (MFB). Anthropology of Food. 2015; https://journals. openedition.org/aof/7735. Accessed 23 Nov 2019.

55. Timothy DJ, Ron AS. Understanding heritage cuisines and tourism: identity, image, authenticity, and change. J Herit Tour. 2013;8(2-3):99-104.

56. Department of Agriculture. Agricooltour: Discover the ATI Learning Sites. Department of Agriculture, Quezon City. 2017. http://ati.da.gov.ph/atimain/ sites/default/files/publications/ATI_Access_April-June2017\%20issue.pdf. Accessed 23 Nov 2019.

57. Sta. Romana-Cruz, N., Sta. Ana, K. Don't take a bath on Friday: Philippine superstitions and folk beliefs. Manila: Tahanan Books; 1996.

58. Lumen, N. Republic of Pancit. The Investigative Reporting Quarterly. Philippine Center for Investigative Journalism. 2005. http://pcij.org/ireport/1/pancit.html. Accessed 23 Nov 2019.

\section{Publisher's Note}

Springer Nature remains neutral with regard to jurisdictional claims in published maps and institutional affiliations.

\section{Ready to submit your research? Choose BMC and benefit from:}

- fast, convenient online submission

- thorough peer review by experienced researchers in your field

- rapid publication on acceptance

- support for research data, including large and complex data types

- gold Open Access which fosters wider collaboration and increased citations

- maximum visibility for your research: over $100 \mathrm{M}$ website views per year

At $\mathrm{BMC}$, research is always in progress.

Learn more biomedcentral.com/submissions 